Izabella Smentek

Papieski Wydziat Teologiczny w Warszawie

\title{
Czy współczesny Kościół modli się o Paruzję? Inspirowana przez Ducha Świętego prośba o powtórne przyjście Chrystusa we współczesnej liturgii Kościoła w Polsce
}

\section{IS THE CHURCH OF TODAY PRAYING FOR THE PAROUSIA? THE HOLY SPIRIT- INSPIRED PLEA FOR THE SECOND COMING OF CHRIST IN THE LITURGY}

Does the contemporary Church pray for the parousia? The article takes into account the contemporary liturgical texts. According to the words of Apocalypsis, the Holy Spirit inspires the joyful prayer for the parousia. That's why this prayer, if actually present, can be treated as the source of light on the intrinsic activity of the Holy Spirit in the Church.

In the Missal and Divine Office many texts concerning the final coming of Lord can be found. Predominantly in advent, claims like: "Maranatha. Come, Lord Jesus" are to be heard. Does it mean that the Church really requests the God to accomplish the story of this world? It seams difficult to distinguish, especially in the eucharistic worship, between the liturgical retrospection, the prayer for sacramental coming of our Lord here and now, His very presence in our history and the claim for eschatological fulfillment.

Apart from this, we find numerous prayers for help, in order that we could prepare ourselves for the events next to parousia, that is for the Last Judgement and resurrection. The Church also humily asks the Lord Jesus and God the Father for overcoming the death, merciful judgement, for the final justice, for the elimination of every evil and resurrection in glory for the believers. But can we say that the voice of the Church - the Bride missing the final presence 
of the Saviour, is to be heard in contemporary liturgical worship? Theologians, like e.g. Joseph Ratzinger, suppose, we cannot dare to express this prayer nowadays as the author of "Didache" did. However, wherever even in timid form appears the prayer for parousia, we hear in it the joyful claim of the Holy Spirit who encourages the Church to desire the full presence of the Lord, the unique divine justice and to wait for the eternal fulfillment in the community of resurrection..

Key words: Holy Spirit, parousia, Church, liturgy, peace and joy.

\section{Eklezjalne vestigia Ducha Świętego}

\section{Poznanie działania Ducha Świętego w modlitwie Kościoła}

Przed teologami staje zadanie, aby wskazać, w jaki sposób przez refleksję nad życiem Kościoła można odsłonić coś z tajemnicy Ducha Świętego. Czymś zwyczajnym byłoby opisywanie Kościoła według kształtującej jego istotę tajemnicy trynitarnej - jako Ludu Bożego, Mistycznego Ciała Chrystusa, Świątyni Ducha Świętego. Czy możliwe jest przyjęcie niejako odwrotnego kierunku? Czy można „odsłonić coś z tajemnicy Ducha”, czy uprawnione jest stawianie sobie takich zadań, skoro Objawienie zakończyło się wraz ze śmiercią ostatniego Apostoła? Sformułowanie „odsłonić coś z tajemnicy” nie uzurpuje sobie prawa do uzupełniania Objawienia, a jedynie wyraża pragnienie pogłębiania refleksji dotyczącej Trzeciej Osoby Trójcy Świętej. Właśnie takie pragnienie odkrywania i wyrażania w każdej epoce niezmiennej tajemnicy przedwiecznego Boga stanowi czynnik ożywiający teologię.

Gdzie zatem można znaleźć vestigia Ducha Świętego w misterium Kościoła? Skoro Duch ożywia Kościół, skoro stanowi zasadę jego jedności i działania, nie można sądzić, że Jego wpływ ogranicza się do jakiegoś jednego, czy kilku aspektów życia wspólnoty eklezjalnej. Działanie Parakleta obejmuje istnienie Kościoła jako całości, ożywia je i kształtuje. Specyficznym przejawem Jego twórczej obecności jest inspirowana i kierowana przez Niego modlitwa. Kościół wyrasta przecież z otwartego na zstąpienie Ducha Wieczernika. „Nikt też nie może powiedzieć bez pomocy Ducha Świętego: «Panem jest Jezus»" (1 Kor 12,3). Ten, który jest wzajemną Miłością Ojca i Syna, sprawia, że człowiek i zjednoczona na sposób sakramentu wspólnota ${ }^{1}$ rzeczywiście zwraca się do Boga Trójjedynego. To On prowadzi naszą modlitwę

Por. Konstytucja Lumen gentium (dalej: KK) 1. 
i daje w niej o sobie znać ${ }^{2}$. Dzięki Niemu modlitwa odbywa się zgodnie z logiką trynitarną, to znaczy otwiera przez Chrystusa i w Chrystusie na kontemplację Ojca ${ }^{3}$.

Skoro zgodnie z zasadą lex orandi lex credendi na podstawie modlitwy Kościoła można odczytać to, w co wierzy i czym żyje wspólnota wiary, czyli jak działa w niej ożywiający ją Duch Święty, powstaje pytanie: W jakiej modlitwie można oczekiwać najbardziej skondensowanego działania Ducha? Odpowiedź daje Pismo Święte: „Duch i Oblubienica mówią: «Przyjdź!»" (Ap 22, 17). Ze słów autora natchnionej księgi dowiadujemy się, że przez wieki modlitwa Kościoła - Oblubienicy o Paruzję będzie zanoszona wraz z Duchem Świętym i przez Niego inspirowana. Można się więc spodziewać odkrycia w niej „czegoś z tajemnicy Ducha"prowadzącego Kościól. Duch, który ziemskie pielgrzymowanie przenika tchnieniem życia wiecznego, kieruje całe stworzenie, całe dzieje do ostatecznego kresu w nieskończoności Boga 4 .

Nieprzypadkowo autor Apokalipsy pisze, że Duch i Oblubienica mówią: „Przyjdź”. Właśnie prośba o Paruzję wyraża oblubieńczy charakter więzi Chrystusa i Kościoła. Kościół określony jako Lud Boży oczekuje sądu. Nawet jeśli prosi o przyjście Pana w nadziei sprawiedliwości i wybawienia, to możemy się doszukiwać w takim ujęciu motywacji oczekiwania dóbr od Zbawcy, a nie przede wszystkim Jego samego. Metafora Oblubienicy podkreśla pragnienie pełnej obecności Zbawiciela, które przeważa nad obawą, związaną z poczuciem własnej niedoskonałości. Na pierwszy plan wysuwa się motywacja miłości do Pana; miłości wzbudzanej przez Ducha Świętego. Wśród modlitw Kościoła, również współczesnego, należy spodziewać się więc prośby tego rodzaju:

„Przyjdź, Panie Jezu wraz ze świętymi, w chwale i w blasku obłoku. Niech Śmierć i Otchłań już nie tryumfują. Niech żywioły tego świata, ziemia i morze wydadzą Twoich zmarłych (por. Ap 20,13) i niech nastąpi wreszcie zmartwychwstanie i życie wieczne”, albo: „Przyjdź, Panie Jezu, przemień ten świat według odwiecznego zamysłu Ojca. Przyjdź, Panie Jezu, do nas sądzonych według tego, co bez znaczenia. Przyjdź, i osądź według jedynego istotnego kryterium: według osobowej Prawdy, którą Ty sam jesteś”.

Czy taką modlitwę - nie dosłownie, ale co do treści - zanosi współczesny Kościół? Ta część Kościoła, która jest w niebie, woła bezustannie (por. Ap 7, 15), wielkim głosem i z niecierpliwością (por. Ap 6, 10)

Por. Jan Paweł II, Encyklika Dominum et vivificantem (dalej: DeV) 65 .

3 Por. tenże, Adhortacja Novo millenio ineunte (dalej: NMiE) 32.

Por. DeV 64. 
Teologia pastoralna

o Paruzję i ostateczną, zbawczą sprawiedliwość. Święty Jan Paweł II pisze, że kierowany przez Ducha Świętego Kościół stale przyzywa powrotu Pana ${ }^{5}$. Thomas Merton nazywał w połowie XX wieku pragnienie wyczekiwania objawienia się chwały Boga w Chrystusowej Paruzji największą potrzebą „naszych czasów”6. Czy chodzi jedynie o „nasze czasy” i tylko o „wyczekiwanie”? To sformułowanie należy uznać za niewystarczające, gdyż sugeruje bierność. Wołanie o przyjście Pana to potrzeba, ale i zarazem, zadanie Kościoła. Chrystus przychodzi na prośbę Ducha i Oblubienicy ${ }^{7}$. Należy zatem wnioskować, że modlitwa o Jego przyjście znajduje się wśród próśb, które Kościół kierowany przez Ducha stale zanosi do Boga. Jeżeli tak, to w pierwszej kolejności trzeba jej szukać nie w przejawach prywatnej pobożności, czy wśród niezliczonych wspólnot charyzmatycznych, ale w oficjalnej liturgii, ponieważ to ona ma szczególny walor locus theologicus dla dogmatycznej refleksji.

\section{Liturgia jako obszar badań teologii dogmatycznej}

Potraktowanie liturgii jako podstawy refleksji dogmatycznej wymaga założenia, że liturgia rzeczywiście odpowiada wierze Kościoła oraz że odbywa się w niej przekaz Objawienia. W modlitwie Kościoła symbole wiary są proklamowane i uobecniane ${ }^{8}$.

Prawdziwość takiej tezy wielokrotnie potwierdza Magisterium Kościoła. Już Celestyn I mówi, że norma modlitwy ustala normę wiary. ${ }^{9}$ Co to znaczy? Liturgia publicznie świadczy o wierze. Nie określa jej swoją mocą, lecz może dostarczyć argumentów i świadectw, ponieważ podlega Magisterium ${ }^{10}$. Nie stwarza wiary, lecz raczej idzie za nią ${ }^{11}$. Pius XI zauważa, że nawet wierni o wyższej kulturze umysłowej mogą dzięki liturgii uzupełnić swoje wiadomości teologiczne ${ }^{12}$.

$5 \quad$ Por. Jan Paweł II, adhortacja Orientale Lumen (dalej: OL) 8.

6 Por. T. Merton, Modlitwa kontemplacyjna, przeł. M. Dybowski, Poznań 1986, s. 107.

7 Por. J. Warzeszak, Pneumatologia wspótczesna, Warszawa 2009, 294.

Por. A. Dulles, The craft of theology. From symbol to system, Crosssroad 1992, 19; Models of revelation, New York 1985, 140.

Por. S. Głowa, I. Bieda (red.), Breviarium fidei, Poznań 1989 (dalej: BF), Indiculus, VII, 630.

$10 \quad$ Por. tamże, Mediator Dei, VII, 635.

11 Por. tamże, Munificentissimus Deus, VII, 636.

12 Por. tamże, Divini cultus, VII, 634. 
Współczesna teologia podkreśla, że liturgia stanowi locus thelogicus jako przestrzeń rezonansu wiary. Odzwierciedla jej historyczny kształt. Świadczy o tym, czym żyje Kościół. Może być przedmiotem badań dogmatyki rozumianej jako refleksja nad wiarą ${ }^{13}$. Można w niej poznać człowieka modlącego się ${ }^{14}$. Nie tylko. Liturgia to przecież także działanie Chrystusa w Kościele, uobecnienie Jego misterium ${ }^{15}$. Dlatego najwięcej mówi o Kościele, o jego odniesieniu do Chrystusa ta modlitwa, która wybrzmiewa w liturgii. W misterium Chrystusa wprowadza Duch Święty. To dzięki Niemu liturgia zyskuje swą sakramentalną skuteczność ${ }^{16}$. Staje się rzeczywistością, nie tylko znakiem. Zawiera w sobie i przedstawia Bogu rzeczywistość Kościoła ożywionego działaniem Ducha Świętego. Liturgia okazuje się więc najwłaściwszą przestrzenią dla zadania postawionego przez organizatorów sympozjum; poszukiwania i odkrywania działania Ducha Świętego w doświadczeniu Kościoła. Szczególne miejsce w tym obszarze zajmuje Mszat i Liturgia Godzin. To Mszat - najważniejsza księga modlitwy i to modlitwy trynitarnej ${ }^{17}$ - ukazuje wiarę Kościoła ${ }^{18}$. Stanowi więc istotne źródło teologiczne.

Jeżeli liturgia wyraża to, w co i jak wierzy Kościól, to również i to, że Lud Boży - Oblubienica nie tylko wierzy w Paruzję i jej oczekuje, ale również to, jak oczekuje, czyli jak żyje inspiracją Ducha Świętego. Prośba o Paruzję stanowi więc szczególny styk wiary i modlitwy Kościoła tak, jak uprzedzająco mówi o niej autor Apokalipsy. Odnośnie wiary wystarczyłoby powiedzieć, że Kościół wierzy w powtórne przyjście Pana i tę wiarę wyznaje. Modlitwa o Paruzję to wyraz postawy, tęsknoty, dążenia, jednym słowem - sposobu życia inspirowanego przez Ducha Ożywiciela. Kościół, który modli się o Paruzję, żyje nadzieją i wychodzi naprzeciw nadchodzącego Pana. Tę prawdę oddaje metafora Kościoła - Oblubienicy oznaczającej wspólnotę uczniów oczekujących z miłością swego Zbawiciela.

13 Por. J. Knop, Ecclesia orans. Liturgie als Herausforderung für die Dogmatik, Freiburg - Basel - Wien 2012, s. 10-14.

Por. tamże, s. 16.

Por. tamże, s. 34; J. Ratzinger, Kościót - znak wśród narodów. Pisma eklezjologiczne i ekumeniczne, [w:] K. Góźdź, M. Górecka (red.), Opera omnia, t. VIII/1, przeł. W. Szymona, Lublin 2013, s. 152n.

Por. J. Knop, Ecclesia..., dz. cyt., s. 35.

Por. J. Miazek, Trzecie wydanie Mszatu Rzymskiego Pawła VI, „Warszawskie Studia Teologiczne" XVI/2003, s. 181.

Por. C. Giraudo, „In unum corpus”. Wymiareschatologicznyepiklezyanaforycznej, [w:] K. Porosło (red.), „A świątyni w nim nie dojrzałem...”'Liturgia i eschatologia, Tyniec 2012, s. 133. 


\section{Paruzja i liturgia}

Zdaniem Margaret Barker, pierwsi chrześcijanie spodziewali się Paruzji jeszcze za swego życia i w tym znaczeniu używali w liturgii wezwania: „Maranatha”. Po okresie apostolskim nastąpił zwrot ku rozumieniu tego wyrażenia jako prośby o przyjście Pana w Eucharystii ${ }^{19}$. W starożytnym Didache znajduje się wypowiedziana wprost prośba: „Niech przeminie ten świat”"20. Patrologowie zapewniają, że właśnie sformułowanie „niech przeminie”, a nie „niech przemieni” (łaska) jest prawidłowe i wyraża tęsknotę za przyjściem Chrystusa. Eschatyczny pastoralna charakter prośby podkreśla zakończenie tekstu: „Przyjdź, Panie Jezu”. Jest ona włączona w kontekst dziękczynienia, co przywodzi na myśl jeden ze śladów działania Ducha Świętego - wdzięczność.

Teologowie zwracają uwagę na silnie wyrażone oczekiwanie Paruzji $\mathrm{w}$ wywodzącej się z Bizancjum liturgii wschodniej. Oczekiwanie to daje się z łatwością zauważyć nie tylko w słowach, ale i w architekturze sakralnej i w samej formie liturgii ${ }^{21}$. Również liturgia zachodnia, choć może w mniej spektakularny sposób, zwraca się ku Bogu, który przychodzi ${ }^{22}$. Już sama, przestrzegana w średniowieczu, a zarzucona później, orientacja architektoniczna świątyni mówiła o poszukiwaniu i oczekiwaniu ojczyzny niebieskiej ${ }^{23}$. Joseph Ratzinger mówi w tym kontekście o paruzyjnym ukierunkowaniu liturgii, o gotowości proklamowanej bez słów ${ }^{24}$. Symbolika ta była obecna w liturgii trydenckiej, kiedy lud i kapłan zwracali się wspólnie w jednym kierunku, ku przychodzącemu Chrystusowi ${ }^{25}$. Chcąc ją przypomnieć, Benedykt XVI wprowadził praktykę umieszczania krzyża na środku ołtarza, na wprost celebransa, tak, aby - podobnie jak w kościołach orientowanych - wszyscy patrzyli w kierunku nadchodzącego Zbawiciela ${ }^{26}$.

19

Por. M. Barker, Parousia and Liturgy, http://www.thinlyveiled.com/barker/ parousia.htm.

Por. Nauka dwunastu Apostotów (Didache), [w:] M. Starowieyski (red.), Pierwsi świadkowie, przeł. A. Świderkówna, Kraków 1998, s. 38.

Por. P. Nowakowski, Eschatologiczny charakter liturgii wschodniej obrzadku bizantyjskiego, [w:] A świątyni..., dz. cyt., s. 56, 71-73.

Por. K. Porosło, „Już” $i$,,jeszcze nie” - liturgia jako eschaton, [w:] A światyni..., dz. cyt., s. 195.

Por. M. Zachara, Eschatologiczny wymiar chrztu $i$ Eucharystii w wybranych świadectwach z I tysiaclecia, [w:] A świątyni..., dz. cyt., s. 48.

Por. J. Ratzinger, Teologia liturgii. Sakramentalne podstawy życia chrześcijańskiego, t. XI, [w:] Opera omnia..., dz. cyt., s. 67.

Por. tamże, s. 74n.

Por. K. Porosło, „Jü’’..., dz. cyt., s. 197n. 
Już sam rok liturgiczny łączy w sobie dwa aspekty: antycypacji uczty niebiańskiej ${ }^{27}$ i odsłaniania misterium Chrystusa w postawie nadziei i oczekiwania Jego powtórnego przyjścia ${ }^{28}$.

Biorąc pod uwagę teksty liturgiczne docieramy do tego, co Kościół mówi o sobie i to własnymi słowami. Jednocześnie w słowach tych rozbrzmiewa głos Ducha Świętego, który prowadzi zgromadzenie liturgiczne i zwraca jego myśli w kierunku eschatonu ${ }^{29}$. Liturgiczne wołanie o przyjście Pana uwzględnia potrójną interpretację - przychodzenie tu i teraz, w Eucharystii i całej rzeczywistości Kościoła oraz przyjście na końcu czasów. Katechizm Kościoła Katolickiego zapewnia jednak, że liturgia i Eucharystia są zawsze ukierunkowane eschatycznie ${ }^{30}$.

\section{Prośby o właściwe przygotowanie do Paruzji}

\section{Prośba o właściwą dyspozycję}

Obok próśb o nadzieję w tekstach liturgicznych nie brakuje stwierdzeń, że mamy ufność i z nadzieją oczekujemy powtórnego przyjścia Pana $^{31}$. Zgromadzenie liturgiczne wyznaje, że Chrystus powróci w chwale ${ }^{32}$ oraz to, że Kościół potrzebuje wsparcia z wysoka w swym oczekiwaniu ${ }^{33}$.

Kościół prosi o nadzieję, ale również przyznaje się do mocnej nadziei $^{34}$. Zdania mówiące, że oczekujemy, dotyczą zarówno Paruzji ${ }^{35}$, jak i tego, co spodziewamy się otrzymać po niej ${ }^{36}$. Modlitwy eucharystyczne obfitują w stonowane stwierdzenia, bez podkreślenia intensywności

27 Por. P.-M. Gy, L'eschatologie de la liturgie en notre temps, „La Maison - Dieu”, 209(1997), n 1, s. 43-45.

28 Konstytucja Sacrosanctum Concilium (dalej: KL) 102.

29 Por.R.Woźniak, „Adfuturam reimemoriam”-liturgia,chrześcijańskakoncepcja czasu $i$,ta eschata”, [w:] A świątyni..., dz. cyt., s. 167.

Por. Katechizm Kościoła Katolickiego (dalej: KKK) 1130, 1403, 2772

Por. Aklamacja po Przeistoczeniu, [w:] Mszalik..., dz. cyt., s. 482.

Por. Obrzędy wstępne Mszy św., [w:] Mszat z czytaniami. Niedziele..., dz. cyt., s. 574.

Por. 3 Prefacja o Najświętszej Maryi Pannie, [w:] Mszalik..., dz. cyt., s. 450.

Por. I Modlitwa eucharystyczna, [w:] Mszat z czytaniami. Niedziele..., dz. cyt., s. 671; 5 Prefacja zwykta, tamże, s. 640. 
Teologia pastoralna oczekiwania ${ }^{37}$. Podobnie twierdzący charakter mają prefacje o świętych, które mówią o zmaganiach koniecznych, aby osiągnąć wieczną nagrodę. Ich tematem jest związany $\mathrm{z}$ tym wysiłek moralny i nagroda $\mathrm{w}$ aspekcie indywidualnym ${ }^{38}$. Bardziej emocjonalne zabarwienie napotykamy natomiast $\mathrm{w}$ hymnach brewiarzowych, gdzie Paruzja kojarzona jest metaforycznie z ,zorzą słońca wieczności” ${ }^{39} \mathrm{i}$ „blaskiem zwycięskiego Chrystusa", przed którym ustępują ciemności ${ }^{40}$. Oczekiwaniu towarzyszy tu już nie ton obojętny, ale afirmacja spodziewanej przyszłości. Żądanie, aby ciemności ustąpiły, to już wezwanie do aktywnego przygotowania do Paruzji.

3 Prefacja o Najświętszej Maryi Pannie mówi, że Maryja wspiera Kościół w dążeniu do wiecznej ojczyzny, aż nadejdzie dzień Pański" Jest to raczej stwierdzenie niż prośba, ale wspomina o pewnej aktywności; o dążeniu, które jest wychodzeniem naprzeciw przybywającego Chrystusa. Kościół pragnie właściwie spożytkować to dążenie. Liturgia Adwentu często powtarza wołanie: „Przyjdź, Panie Jezu”. Nie zawsze jednak można powiedzieć, że ma ono znaczenie prośby wprost o Paruzję. Niekiedy kontekst wskazuje na to, że chodzi np. o właściwą postawę oczekiwania, tj., pobożnie, w miłości, bez pokus, oraz o wyznanie wiary w powtórne przyjście Zbawiciela ${ }^{42}$. Kościół modli się w adwentowej liturgii o odpowiednie przygotowanie na przyjście Pana. Dotyczy to Jego wielokrotnego przychodzenia w historii ${ }^{43}$, ale i tego ostatecznego w chwale, w dzień sądu ${ }^{44}$. Podobne treści pojawiają się zresztą i w innych momentach roku liturgicznego ${ }^{45}$. Są to prośby zanoszone do Boga Ojca, a nie bezpośrednio kierowane do Chrystusa: „Przyjdź, czekamy”.

Prośba o właściwą dyspozycję oczekiwania dotyczy czujności i - w kontekście sądu - zachowania od grzechów, niekiedy konkretnie

$37 \quad$ Por. III Modlitwa eucharystyczna, tamże, s. 590n.

38 Por. Prefacje o świętych, [w:] Mszalik..., dz. cyt., s. 455.

39 Por. Hymny jutrzni. Niedziela I i III tygodnia, [w:] Liturgia Godzin, t. IV, Pallottinum 1988, s. 523, 751.

$40 \quad$ Por. Hymn jutrzni. Środa I tygodnia, tamże, s. 571.

41 Por. 3 Prefacja o Najświętszej Maryi Pannie, [w:] Mszalik..., dz. cyt., s. 450.

Por. Prośby i modlitwa jutrzni. II niedziela adwentu, [w:] Liturgia Godzin, t. I, Pallottinum 1982, s. 188.

Por. Kolekta. I niedziela adwentu, [w:] Mszat z czytaniami. Niedziele..., dz. cyt., s. 29; Kolekta. Poniedziałek I tygodnia adwentu, tamże, s. 36.

Por. Kolekty I tygodnia adwentu, tamże, s. 42. 
wymienionych ${ }^{46}$. Właściwe przygotowanie to również wysiłek wiernych i o to również modli się Kościół świadomy, że wartość eschatyczną mają tylko te czyny, które są „dokonane w duchu” ${ }^{47}$. Niektóre sentencje liturgiczne koncentrują się na aspekcie moralnym, na osobistym uświęceniu przez upodobnienie do Chrystusa, na indywidualnym przygotowaniu do życia wiecznego ${ }^{48}$. Prośby o właściwą dyspozycję na przyjście Pana wymieniają też poszczególne elementy takiej gotowości, a więc mocną wiarę, nadzieję i miłośćc ${ }^{49}$. Kościół prosi, aby przyjściu Chrystusa - Sędziego towarzyszyła radość świętych, a nie trwoga ${ }^{50}$. Nie jest to jednak jeszcze wołanie: „Przyjdź, osądź!”

Ze stwierdzeniami, że wierzymy i oczekujemy, wiąże się prośba o to, byśmy właściwie oczekiwali i byli przygotowani. Dotyczy to wszystkiego, co ma miejsce przed Paruzją. Tu również należy wspomnieć te teksty, w których silnej akcentuje się historyczno-liturgiczne uobecnianie i antycypację przyjścia Pana oraz skutki zbawczego dzieła potrzebne w doczesnej drodze Kościoła ${ }^{51}$. W perspektywie Paruzji, nie tracąc z oczu przyszłości, ale właśnie ze względu na nią, Kościół modli się o to, co potrzebne w drodze. Stąd dwoisty niekiedy wydźwięk takiej modlitwy. Wydaje się np., że sformułowanie: „Przybądź, Panie” dotyczy wprost powtórnego przyjścia Zbawiciela, ale towarzyszące takiemu wołaniu prośby wskazują, że chodzi o Jego przychodzenie w doczesności; o uwolnienie od grzechu i odsunięcie pokus ${ }^{52}$, o okazanie

$46 \quad$ Por. Kolekta 3 niedzieli wielkanocnej, [w:] Mszat z czytaniami. Niedziele..., dz. cyt., s. 1056; Modlitwa I niedzieli adwentu, [w:] Liturgia Godzin, t. I..., dz. cyt., s. 140; Prośbyjutrzni. Czwartek 1 tygodnia adwentu, tamże s. 167; Prośbyjutrzni. Poniedziałek 2 tygodnia adwentu, tamże, s. 195.

Por. Kolekta. 1 niedziela adwentu, [w:] Mszalik..., dz. cyt., s. 31.

Por. Modlitwa po Komunii. 20 niedziela zwykła, tamże, s. 913; Modlitwa kapłana po „Ojcze nasz”, tamże, s. 513; Modlitwa nad darami i po Komunii Św. I niedziela adwentu, tamże, s. 34, 38, 41; Kolekta. Piątek II tygodnia adwentu, [w:] Mszat z czytaniami. Niedziele..., dz. cyt., s. 70.

Por. Obrzędy chrztu, [w:] Mszalik..., dz. cyt., s. 1096; Modlitwa popotudniowa wadwencie, [w:] Liturgia Godzin, t. I..., dz. cyt., s. 132; Prośby Jutrzni. Czwartek Oktawy Wielkiejnocy, [w:] Liturgia Godzin, t. II, Pallotinum 1984, s. 471.

Por. Kolekta. Środa 6 tygodnia wielkanocnego, [w:] Mszat z czytaniami. Niedziele..., dz. cyt., s. 566; Kolekta wieczornej mszy wigilijnej, tamże, s. 124.

Por. np. Antyfony przed Ewangelia 21. XII, tamże, s. 115.

Por. Hymn Godziny czytań. Piątek II tygodnia, [w:] Liturgia Godzin, t. III, Pallotinum 1987, 760 . 
wiernym łaskawości ${ }^{53}$, o pomoc w opanowaniu trosk doczesnych ${ }^{54}$, o obudzenie wiary i wzrost cnót ${ }^{55}$, Do tej „,przedparuzyjnej” grupy należą także zanoszone ze względu na dzień Pański prośby o wzrost Kościoła i zbawienie świata ${ }^{56}$.

\section{Pneumatologiczna wymowa próśb o to, co przed Paruzją}

Powyższe modlitwy wyrażają gotowość i pewność Paruzji, stanowią prośby o właściwe do niej przygotowanie, ale nie bezpośrednio o przyj-

Teologia pastoralna ście Pana. Nie mają charakteru przynaglenia czy niecierpliwości. Jak przy każdej modlitwie, tak i tu można zauważyć i wskazać inspirację Ducha Świętego. Gdy Kościół prosi o właściwą dyspozycję wobec zapowiedzianego dnia Pańskiego, działający w nim Duch Pocieszyciel umacnia nadzieję i poucza o grzechu.

Duch Święty sprawia przychodzenie Chrystusa w rzeczywistości sakramentalnej. Najpełniej odbywa się to w Eucharystii ${ }^{57}$. Dlatego nawet modlitwa: „Przybądź, o Panie, aby nas wybawić" ${ }^{58}$, może być rozumiana jako wołanie o bliskość Pana teraz, w drodze. $Z$ jednej strony prośba o Paruzję we Mszy św. wydaje się nie na miejscu, bo przecież Eucharystia to już uobecnianie chwały. Z drugiej strony wyznajemy, że oczekiwanie wciąż trwa. Liturgia daje przedsmak nieba, zadatek przyszłej chwały, ale to nie kończy oczekiwania ${ }^{59}$. Przeplatają się w niej elementy zrealizowane i niedokonane w eschatologii. Eucharystyczne przychodzenie, obejmujące antycypację przyszłości i udział w wiecznym życiu Boga, zostaje zrównoważone przez wyznanie oczekiwania. Nie jest ono jedynie bierne. Jest przepojone czujnością i związane $\mathrm{z}$ wysiłkiem moralnym ${ }^{60}$. Zarówno eucharystyczne uobecnianie ostatecznego zwycięstwa Chrystusa, a więc Jego Paruzji, jak i pełne gotowości oczekiwanie Kościoła odbywa się „przez moc Ducha Świętego”

53 Por. Prośby jutrzni, środa I tygodnia adwentu, [w:] Liturgia Godzin, t. I..., dz. cyt., 207.

Por. Kolekta. 2 niedziela adwentu, [w:] Mszalik..., dz. cyt., 42.

Por. Prośby jutrzni 1 tygodnia adwentu, [w:] Liturgia Godzin, t. I..., dz. cyt., 146; Prośby nieszporów 1 tygodnia adwentu, tamże, 148n.

Por. I modlitwa eucharystyczna, [w:] Mszat z czytaniami. Niedziele..., dz. cyt., 1516; Modlitwa po Komunii Św. 5 niedziela zwykła, [w:] Mszalik..., dz. cyt., 560. Por. DeV 61-62.

Por. Prośby nieszporów. Wtorek 1 tygodnia adwentu, [w:] Liturgia Godzin, t. I..., dz. cyt., 156.

Por. KL 6. 
(KL 6). Czy jednak można odnaleźć prośbę skierowaną wyłącznie ku przyszłości, podobną do tej z Didache - „Przyjdź i niech przeminie ten świat"?

\section{Prośby o to, co w wyniku Paruzji}

W I tygodniu Adwentu Kościół prosi Boga o wybawienie od śmierci, rozproszenie niewiedzy, okazanie łaskawości i dopuszczenie do „domu wesela”. Każdej z tych próśb towarzyszy wezwanie: „Przybądź, Panie Jezu" ${ }^{61}$. Każda może być interpretowana dwojako - oczekiwane dobra mogą być udzielane teraz, w doczesności i ostatecznie, na końcu czasu. Teologia Natomiast prośba o wybawienie od śmierci wiąże się jednoznacznie z Paruzją. Przyjście Pana przyniesie przecież zbawienie, sprawiedliwość, uwolnienie od zła, pokój, wolność. Są to „dobra mesjańskie”, których świat zakosztował już przy pierwszym Jego przyjściu (por. Łk 4,18) i które stale są obecne w Kościele jako „owoce Ducha” (por. Ga 5, 22), a w ostatecznej formie będą nam dane w wyniku Paruzji. Wszędzie tam, gdzie pojawia się prośba o zmartwychwstanie, o ostateczne uwolnienie od zła, o wieczność, należy ją uznać za modlitwę o powtórne przyjście Chrystusa, które warunkuje udzielenie tych dóbr. Można powiedzieć, że we wszystkich tych momentach Kościół modli się o powrót Zbawiciela, ale nie wprost. Czasami, jak np. w skróconej formie wyznania wiary, pomija się Paruzję, a wymienia się jej następstwa - zmartwychwstanie i życie wieczne ${ }^{62}$. Wśród próśb o to, co ma nastąpić w wyniku Paruzji, szczególne miejsce zajmują te dotyczące udziału w chwale zmartwychwstania, obejmujące tak Kościół jako całość, jak i poszczególnych wiernych.

\section{Modlitwy za zmarłych}

Paruzja i śmierć to przeciwieństwa. Przyjście Chrystusa całkowicie i na zawsze eliminuje śmierć i usuwa jej skutki. Można więc się spodziewać, że wołanie o Paruzję znajdzie się wśród modlitw za zmarłych obok próśb o miłosierdzie.

W modlitwach za zmarłych znajdujemy, podobnie jak w przytoczonych powyżej tekstach, prośby o nadzieję związaną ze zmartwychwstaniem ${ }^{63}$,

61 Por. Prośby nieszporów. Czwartek 1 tygodnia adwentu, tamże, s. 169.

62 Por. Odnowienie przyrzeczeń chrztu, [w:] Mszat z czytaniami. Niedziele..., dz. cyt., s. 289.

$63 \quad$ Por. Kolekta. Msza pogrzebowa w okresie wielkanocnym, tamże, s. 1496; Prośby nieszporów. Oficjum za zmartych, Liturgia Godzin, t. III..., dz. cyt., s. 1652n. 
a także deklarację ufności w powstanie z martwych ${ }^{64}$. Wyznaniu wiary w powszechne zmartwychwstanie towarzyszy prośba o to, co nastąpi po nim, a więc o zbawienie, ale także o radość dla zmarłych już teraz jeszcze przed powszechnym powstaniem $z$ martwych ${ }^{65}$. W tych stwierdzeniach i prośbach daje się odczuć przynajmniej afirmacja Paruzji ${ }^{66}$ i pewien ton przynaglenia ${ }^{67}$. Skierowana do Boga Ojca prośba o „pełnię wiecznej radości” wskazuje, że chodzi o ,pełnię Chrystusa” przy dopełnieniu się zbawczego planu ${ }^{68}$. Słowa hymnu mówiące o wydźwignięciu do Ojca za sprawą Chrystusa zmartwychwstałego ${ }^{69}$ współbrzmią

Teologia pastoralna $\mathrm{z}$ nauką św. Pawła o tym, że podobnie jak On będziemy wskrzeszeni z martwych (por. Rz 8, 11). Brewiarzowy hymn wyraża, bez wzmianki o Paruzji, ufność w zmartwychwstanie na wzór Chrystusa i prosi o nie Ojca. Duch Święty nie zostaje wymieniony. Domyślamy się, że to On ukrywa się za słowami modlitwy. Inspiruje ją i prosi wraz z Kościołem.

W liturgii za zmarłych dominuje troska o ich los - o zbawienie i wieczną radość. Czy zanoszona za zmarłych modlitwa dotyczy tego, co po Paruzji? Albo, czy wyłącznie tego ${ }^{70}$ Interpretacja powinna uwzględnić obydwa aspekty. Po pierwsze, papież Benedykt XII w bulli Benedictus Deus stanowczo potwierdził, że udział zbawionych w widzeniu uszczęśliwiającym rozpoczyna się jeszcze przed ich zmartwychwstaniem ${ }^{71}$. Po drugie, powszechne zmartwychwstanie stanowi w planie Bożym, nie dodatek, ale cel określający pełnię człowieczeństwa. Modlitwa za zmarłych uwzględnia obydwa aspekty. Wymienione w niej ,zmartwychwstanie w chwale” i ,pełnia wiecznej radości” dotyczą zarówno „pełni” w następstwie przyjścia Chrystusa, jak i tego,

64 Por. Hymn Godziny czytań. Oficjum za zmartych, tamże, s. 1625.

65 Por. Modlitwa po Komunii Św., 2 Msza w Dzień Zaduszny, [w:] Mszat ..., dz. cyt., s. 1420; Antyfona na Komunię. Modlitwa po Komunii Św., 3 Msza w Dzień Zaduszny, tamże, s. 1422n.

Por. Antyfona na Komunię. 3 Msza we Wspomnienie Wszystkich Wiernych Zmartych, [w:] Mszat z czytaniami. Niedziele..., dz. cyt., s. 1810.

Por. Prośby II nieszporów niedzieli 2 tygodnia, [w:] Liturgia Godzin, t. IV..., dz. cyt., s. 534.

Por. Modlitwa po Komunii. 3 Msza we Wspomnienie Wszystkich Wiernych Zmartych, [w:] Mszat z czytaniami. Niedziele..., dz. cyt., s. 1810.

Por. Hymn Godziny czytań. Oficjum za zmartych, [w:] Liturgia Godzin, t. II..., dz. cyt., s. 1755.

70 Por.Modlitwa po Komunii. 2 Msza Wspomnienie Wszystkich Wiernych Zmartych, [w:] Mszat z czytaniami. Niedziele..., dz. cyt., s. 1807. 
by zmarli już teraz mieli pewność przebywania $\mathrm{z} \mathrm{Nim}^{72}$. W prośbach adwentowych nieszporów modlitwie o wprowadzenie zmarłych do Królestwa Niebieskiego towarzyszy przynaglenie: „Przybądź, Panie Jezu" i wspomnienie przyszłego sądu ${ }^{73}$. Czy to wystarczy, aby uznać taką modlitwę za wołanie o Paruzję? Nie można jednoznacznie tego powiedzieć, bo przecież „wprowadzenie do Królestwa” dopuszcza także interpretację wyprowadzenia z czyśćca.

Taka podwójna interpretacja okazuje się właściwa przy różnych wariantach próśb o ,zmartwychwstanie w chwale" ". Modlitwa o ,życie wieczne" i powstanie zmarłych do życia" wspomina dzień ostateczny, ale w podtekście zawiera też pragnienie ocalenia od „śmierci drugiej”, przed którą już teraz chroni ,posiadanie życia w sobie" ${ }^{75}$. Za pomocą metafor „domu doczesnej pielgrzymki” i „wiecznego mieszkania w niebie" Prefacja o zmartych mówi o szczęściu zaraz po śmierci, po opuszczeniu tego świata (por. $2 \mathrm{P} 1,13 \mathrm{n}$ ), i o ostatecznym przebywaniu „u Ojca”76. Modlitwy z mszy za zmarłych, chociaż wspominają dzień zmartwychwstania, wyrażają nie tyle tęsknotę za nim, ile troskę o indywidualną dyspozycję zmarłego i o jego $\operatorname{los}^{77}$. Troska ta implikuje działanie Ducha Świętego, który usuwa grzech i jego skutki ${ }^{78}$.

W tekście Mszy św. z Wspomnienia wszystkich wiernych zmartych odnajdujemy ślad myśli o Paruzji ${ }^{79}$. Słowa mówiące o tym, aby wszyscy zmarli zostali wyzwoleni z więzów śmierci, przywodzą na myśl znaną z Apokalipsy ,pełną liczbę współsług i braci”, pełną - na końcu dziejów (por. Ap 6, 11).

Na końcu czasów Chrystus objawia w pełni swoje zwycięstwo. Paruzyjny motyw zwycięskiego Zbawiciela odnajdujemy zarówno

$72 \quad$ Por. Prefacja. Wspomnienie wiernych zmartych, [w:] Mszat z czytaniami. Niedziele..., dz. cyt., s. 1513; Modlitwa po Komunii. 2 listopada, [w:] Mszalik..., dz. cyt., s. 1058.

73 Por. Prośby nieszporów 19 grudnia, [w:] Liturgia Godzin, t. I..., dz. cyt., s. 311.

${ }_{74}$ Por. Prośby nieszporów. Oficjum za zmartych, [w:] Liturgia Godzin, t. I..., dz. cyt., s. 1664.

75 Por. Prośby jutrzni. Oficjum za zmartych, [w:] Liturgia Godzin, t. II..., dz. cyt., s. 1772.

Por. 1 prefacja za zmartych, [w:] Mszat z czytaniami. Niedziele..., dz. cyt., s. 664.

77 Por. Kolekta. Modlitwa po Komunii Św., Msza pogrzebowa w okresie wielkanocnym, tamże, s. 1501; Kolekta. Modlitwa po Komunii Św. Msza w rocznicę śmierci, tamże, s. $1502 \mathrm{n}$.

78 Por. J. Warzeszak, Duch Święty a grzech. Przyczynek do hamartiologii pneumatologicznej, „Warszawskie Studia Teologiczne” XXII/2/2009, s. 166nn.

79 Por. Modlitwa nad darami. Wszystkich wiernych zmartych, [w:] Mszat z czytaniami. Niedziele..., dz. cyt., s. 1809. 
Teologia pastoralna w stonowanych stwierdzeniach, że oczekujemy Paruzji i zmartwychwstania $^{80}$, jak i w prośbach o wskrzeszenie umarłych ${ }^{81}$. O Chrystusowym zwycięstwie nad śmiercią mówią prośby posługujące się opozycją noc/dzień, czy ciemność/światło. Brzmi w nich nuta ponaglenia i niecierpliwości w oczekiwaniu na obudzenie umarłych ${ }^{82}$. Można je więc potraktować jako błagania - nie wprost - o Paruzję. Nieco inny charakter ma Modlitwa nad darami z 2 listopada ${ }^{83} \mathrm{o}$,wyzwolenie $\mathrm{z}$ więzów śmierci” i „udział w życiu wiecznym”. Takie sformułowania implikują dwie interpretacje: chodzi o wyzwolenie z więzów śmierci już, jeszcze przed powszechnym zmartwychwstaniem tych, którzy śmierć mająjuż za sobą i „spoczywają w Chrystusie”, albo o ostateczne wyzwolenie, czyli o uzyskanie człowieczej pełni przy zmartwychwstaniu.

W liturgii nie brak trynitarnego ujęcia tematu zwycięstwa nad śmiercią. Kościół wyznaje w niej i głosi trynitarny porządek zmartwychwstania. Pokłada ufność w Bogu Ojcu, że przywróci zmarłych do życia na wzór Chrystusowego Zmartwychwstania ${ }^{84}$. Prosi, aby to uczynił i wprowadził nas z Nim do chwały ${ }^{85}$. Zwraca się do Ojca i bezpośrednio do Chrystusa ${ }^{86}$. Błaganie o doprowadzenie do chwały Zmartwychwstania zawiera w sobie wołanie o Paruzję, która je warunkuje, a słowa mówiące o „obdarzeniu nowym życiem” wskazują na dyskretną obecność Ducha Ożywiciela w zbawczym dziele. O Nim także, o Duchu, który jest Miłością Trójcy, mówi wielkopostna modlitwa o to, by zmarli „powstawszy w chwale”, cieszyli się miłością Boga na wieki ${ }^{87}$.

Modlitwa o Paruzję wydaje się niedoceniona i dyskretnie ukryta, a jest to przecież - wraz z prośbą o Zmartwychwstanie - par excellence modlitwa za zmarłych, ponieważ dotyczy ostatecznego pokonania śmierci. Gdy Kościół modli się o Paruzję, mieszkańcy nieba i pielgrzymujący na ziemi realizują i umacniają swą jedność, wspólnie

$80 \quad$ Por. Antyfona na Komunię. 2 listopada, [w:] Mszalik..., dz. cyt., s. 1058.

81 Por. Prośby nieszporów. Oficjum za zmartych, [w:] Liturgia Godzin, t. III..., dz. cyt., s. 1652.

Por. Hymn jutrzni. Prośby jutrzni, tamże, s. 1638.

Por. Mszalik..., dz. cyt., s. 1057.

Por. Hymn Godziny czytań. Oficjum za zmartych, [w:] Liturgia Godzin, t. III..., dz. cyt., s. 1625 .

Por. Prośby jutrzni. Oficjum za zmartych, [w:] Liturgia Godzin, t. IV..., dz. cyt., s. 1654.

Por. Modlitwa po Komunii. Podwyższenie Krzyża Świętego, [w:] Mszał z czytaniami. Niedziele..., dz. cyt., s. 1775.

87 dz. cyt., s. 78. 
zwracając się do Boga. Spełnia się wówczas powołanie człowieka i Kościoła do uczestniczenia w dziełach Bożych w tym szczególnym aspekcie: w pokonywaniu śmierci. Powołanie to może realizować się tylko w jeden sposób: dzięki współdziałaniu z Duchem Ożywicielem, Duchem, który jest Sprawcą mistycznej jedności Kościoła. Modlitwa za zmarłych stanowi wyraz jedności i odpowiedzialności wzajemnej poszczególnych części Kościoła. To także wyraz wzajemnej troski, a więc miłości i Komunii, które kształtuje Duch Pocieszyciel.

\section{Modlitwa o zmartwychwstanie}

Prośby związane ze zmartwychwstaniem nie ograniczają się do formularzy związanych z modlitwą za zmarłych. Przy różnych przecież okazjach Kościół modli się o wskrzeszenie umarłych. Można wyróżnić w tych prośbach dwa motywy intonacyjne. Niektóre sformułowania podkreślają sam fakt zmartwychwstania, dzieło Chrystusa i skutek Jego przyjścia. Inne - a tych jest ze zrozumiałych względów znacznie więcej - kładą nacisk na to, by ci, których obejmuje modlitwa, zmartwychwstali w chwale, do życia. Ich motywem jest więc nie tyle tęsknota za dopełnieniem się zbawczego dzieła, ile troska o wynik ostatecznego sądu.

Do pierwszej kategorii można zaliczyć adwentowe wołanie: „Przyjdź, Panie Jezu”. Zawartą w nich prośbę o „przywrócenie życia” można interpretować w aspekcie doczesnym, w którym dotyczy przywrócenia do życia łaski i odpuszczenia grzechów, a także eschatycznym, jako pragnienie zmartwychwstania i życia wiecznego ${ }^{88}$. Co odnajdujemy w tego typu tekstach? Przede wszystkim zawierają wyznanie wiary. Niekiedy, co charakterystyczne, wymieniają skutki Paruzji bez wzmianki o niej samej ${ }^{89}$. Kościół prosi w nich o właściwą dyspozycję, o ufnośćc ${ }^{90}$, bądź deklaruje pewność zmartwychwstania i ufność oczekiwania ${ }^{91}$. Wyważonym prośbom o „nowe życie” tu i teraz, po uwolnieniu od grzechów, i w przyszłości, po Paruzji, towarzyszy ufność i pewność spełnienia się Bożego planu ${ }^{92}$. Czy można w nich odnaleźć również ślad tęsknoty

88

Por. Prośby II nieszporów 4 niedzieli adwentu, [w:] Liturgia Godzin, t. I..., dz. cyt., s. 279.

Por. Wyznanie wiary, [w:] Mszat z czytaniami. Niedziele..., dz. cyt., s. 578.

Por. Kolekta. Modlitwa po Komunii. 3 niedziela wielkanocna, tamże, s. 482.

Por. Antyfona wejście. Msza św. w rocznicé śmierci $w$ okresie wielkanocnym, tamże, s. 1921; Błogosławieństwo w adwencie, [w:] Mszalik..., dz. cyt., s. 519, 521.

Por. Liturgia chrzcielna Wigilii paschalnej, tamże, s. 298; Prośby nieszporów Bożego Ciata, [w:] Liturgia Godzin, t. III..., dz. cyt., s. 511. 
czy niecierpliwości apokaliptycznej Oblubienicy? W brewiarzowej modlitwie Kościół przypomina: „Boże, obiecałeś, że ludzie powstaną z martwych” i woła: „Nie zapomnij na wieki o tych, którzy zeszli

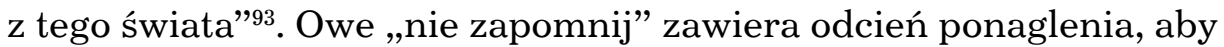
spełnienie obietnicy nie opóźniało się „na wieki”.

W modlitwie Kościoła spotykamy też afirmację przyszłego zmartwychwstania, a więc objawienia się chwały Boga. Jest to wprawdzie nie prośba o Paruzję, ale wyraz radości z tego, że ma nastąpić ${ }^{94}$. W tym tonie brewiarzowy hymn mówi o spotkaniu Chrystusa, do którego ,po-

Teologia pastoralna rwą nas obłoki" i prosi Go, byśmy uczestniczyli w pokonaniu śmierci ${ }^{95}$. Jak rozumieć to „pokonanie śmierci?” Może nim być prowadzone już teraz życie łaski. Jednakże paruzyjna symbolika Chrystusa przychodzącego na obłokach nie pozostawia wątpliwości. Święty Paweł używa tych samych obrazów: w dniu zmartwychwstania będziemy porwani na obłoki, naprzeciw Pana - do Jego sfery bytowania, do Jego przestrzeni życia (por. 1 Tes 4,17). Mamy więc do czynienia, choć jeszcze nie z prośbą o Paruzję, ale $\mathrm{z}$ afirmującym wyznaniem, że nastąpi i to „wkrótce” oraz z prośbą o zmartwychwstanie.

\section{Prośby o „zmartwychwstanie w chwale”}

Prośby o zmartwychwstanie dotyczą pośrednio, w pewien dyskretny sposób, Paruzji, bo przecież w jej wyniku następuje zakończenie, ograniczających się do doczesnego świata, praw śmierci. Zawiera się w nich afirmacja dzieła, a więc także podkreślenie znaczenia Jego powtórnego przyjścia.

Nieco inny wydźwięk mają modlitwy, w których dominuje temat „zmartwychwstania w chwale”. Tu szczególnie zaznaczone zostaje błaganie o zbawienie (proszących, zmarłych, całego Kościoła itd.). Oczywiście nie znaczy to, że w poprzedniej grupie ten aspekt miałby być zaniedbany czy pominięty. Chodzi o nieco inne rozłożenie akcentów. Przedmiotem większości modlitw mówiących o zmartwychwstaniu, co zresztą jest zrozumiałe, jest nie tyle samo zakończenie dziejów, ile ostateczny los tych, których modlitwy dotyczą. „Zmartwychwstanie w chwale" to zmartwychwstanie w Bogu, życie w Bogu (por. J 5, 29). Kościół prosi, aby Chrystus dał udział w swoim zmartwychwstaniu

93 Por. Prośby nieszporów z wtorku 3 tygodnia, [w:] Liturgia Godzin, t. IV..., dz. cyt., s. 795.

Por. Prośby nieszporów z wtorku 4 tygodnia, [w:] Liturgia Godzin, t. III..., dz. cyt., s. 954; Hymn Godziny czytań. Oficjum za zmartych, tamże, s. 1625.

95 Por. Hymn Godziny czytań. Niedziela 1 tygodnia, [w:] Liturgia Godzin, t. IV..., dz. cyt., s. 520. 
tym, którzy Go naśladują ${ }^{96}$. W licznych prośbach o „doprowadzenie do chwały zmartwychwstania" nie należy dopatrywać się ponaglenia. Implikująjednak Paruzję, która stanowi przecież warunek wyzwolenia spod władzy śmierci ${ }^{97}$. Podobny wydźwięk „modlitwy nie - wprost” mają skoncentrowane na doczesności słowa wyrażające troskę o to, by Chrystus przez życie sakramentalne doprowadził wspólnotę wiernych do zmartwychwstania ${ }^{98}$.

W kontekście „zmartwychwstania w chwale” Kościół wypowiada prośby o owocność doczesnej pielgrzymki, a więc życia sakramentalnego i tego wszystkiego, co obejmuje określenie "służenia Bogu" na tym świecie ${ }^{99}$. Modlitwa o „powstanie z martwych w Chrystusie” wyraża ufność i spokój pomimo perspektywy śmierci ${ }^{100}$.

Gdy Kościół prosi o chwałę zmartwychwstania dla tych, którzy zasnęli w pokoju, spogląda nie tylko ku wieczności, ale obejmuje myślą także teraźniejszość zmarłych, dla których źródłem pokoju jest pewność obiecanego zmartwychwstania i możliwość oglądania Boga, jeszcze zanim ono nastąpi ${ }^{101}$. Wezwanie, abyśmy „kiedyś stali się uczestnikami uwielbionego ciała Chrystusa" ${ }^{102}$ niesie w sobie sugestie, że nie stanie się to niebawem.

Por. Błogosławieństwo o Męce Pańskiej, [w:] Mszat z czytaniami. Niedziele..., dz. cyt., s. 718.

Por. Prośby nieszporów z wtorku 4 tygodnia, [w:] Liturgia Godzin, t. IV..., dz. cyt., s. 910; Prośby nieszporów. Piątek po Popielcu, [w:] Liturgia Godzin, t. II..., dz. cyt., s. 63; Prośby nieszporów 1 tygodnia Wielkiego Postu, tamże, s. 79nn; Prośby nieszporów 6 tygodnia wielkanocnego, tamże, s. 709; Modlitwa po Komunii. Wielkanoc, [w:] Mszalik..., dz. cyt., s. 309; Modlitwa po Komunii. 2 niedziela wielkanocna, tamże, s. 330; Kolekta. 4 niedziela adwentu,[w:] Mszatzczytaniami. Niedziele..., dz. cyt., s. 95.

Por. Modlitwa po Komunii. 15 sierpnia, [w:] Mszalik..., dz. cyt., s. 1036; Prośby nieszporów Wielkiego Czwartku, [w:] Liturgia Godzin, t. II..., dz. cyt., s. 359.

Por. Prośby II nieszporów niedzieli woktawie Wielkiejnocy, [w:] Liturgia Godzin, t. II..., dz. cyt., s. 505; Kolekta. Wielka Środa, [w:] Mszat z czytaniami. Niedziele..., dz. cyt., s. 377; Kolekta. Piatek 2 tygodnia wielkanocnego, tamże, s. 477.

Por.Błogosławieństwo wody chrzcielnej. Wigilia paschalna, tamże, s. 286; Prośby jutrzni. Wielki Piatek, [w:] Liturgia Godzin, t. II..., dz. cyt., s. 372; Hymn Godziny Czytań. Oficjum za zmartych, [w:] Liturgia Godzin, t. III..., dz. cyt., s. 1622.

Por. Prośby II nieszporów niedzieli 4 tygodnia, [w:] Liturgia Godzin, t. IV..., dz. cyt., s. 877.

Por. Prośby II nieszporów Niedzieli Palmowej, [w:] Liturgia Godzin, t. II..., dz. cyt., s. 331. 
Modlitwa o zmiłowanie i wybawienie od wszelkich więzów zwraca się do Chrystusa, który jest „zmartwychwstaniem naszym” ${ }^{103}$. W jej tle znajduje się Paruzja - najczęściej nie wymieniana wprost, ale przecież oczywista, jako warunek powstania z martwych. Wezwaniu, zdawałoby się jednoznacznie na nią wskazującemu, „Przybądź, o Panie, aby nas wybawić" - towarzyszą prośby związane z doczesnością, a obok nich inne, odnoszące się do wybawienia od „,́́mierci wiecznej”, czyli od potępienia ${ }^{104}$. Użyte w nich słowo; „wszyscy” każe sądzić, że ich tematem jest ostateczne wybawienie na końcu czasów.

Teologia pastoralna
Czy można wśród tych próśb rozpoznać jednobrzmiący głos Ducha i Oblubienicy? Apokalipsa stosuje synonimy: Oblubienica - Małżonka Baranka - miasto - Jeruzalem Nowe, którego światłem jest Baranek. Symbole Miasta pełnego światła (por. Ap 21, 11; 21, 23nn; 22, 5), czy też towarzyszącego Zbawicielowi orszaku zbawionych wyobrażają Kościół w chwale, po dopełnieniu dziejów. Na ten obraz wskazują teksty mówiące o eschatycznym spotkaniu pokoleń ${ }^{105}$. Tę samą symbolikę „nowego życia w światłości” znajdujemy w modlitwie o dar Ducha Świętego ${ }^{106}$. Jego ślad - Ducha Dawcy radości - odnajdujemy w liturgii mówiącej o zmartwychwstaniu ${ }^{107}$.

Czy można uznać, że teksty liturgiczne dotyczące powszechnego powstania z martwych odnoszą się tym samym do Paruzji? Czy są to prośby o oczywistość, o to, co i tak musi się stać? Na pewno przebija w nich, jeśli nie ponaglenie, to afirmacja Bożego planu wskrzeszenia umarłych. Przeważa jednak, ,aspekt praktyczny”: Paruzja jest pewna, zbawienie - nie dla każdego. Dlatego modlitwy koncentrują się na wyproszeniu tego, co nie jest pewne, na zmartwychwstaniu „ku życiu”. Są kierowane zazwyczaj do Ojca i do Chrystusa. Duch Święty raczej nie jest w nich wymieniany, ale ma przecież także udział w powszechnym powstaniu z martwych: „Ten, co wskrzesił Jezusa z martwych, przywróci do życia wasze śmiertelne ciała mocą mieszkającego w was

103 Por. Litania do Najświętszego Serca Pana Jezusa; Prośby nieszporów 3.01, [w:] Liturgia Godzin, t. I..., dz. cyt., s. 455; Prośby nieszporów 5.01, tamże, s. 469.

Por. Prośby nieszporów z wtorku 3 tygodnia adwentu, [w:] Liturgia Godzin, t. I..., dz. cyt., s. 253.

Por. Kolekta. Zmartwychwstanie Pańskie. Msza św. w dzień, [w:] Mszat z czytaniami. Niedziele..., dz. cyt., s. 296; Hymnjutrzni. Niedziela Wielkanocna, [w:] Liturgia Godzin, t. II..., dz. cyt., s. 410; Prośby II nieszporów niedzieli 1 tygodnia, [w:] Liturgia Godzin, t. III..., dz. cyt., s. 578.

Por. Kolekta. Zmartwychwstanie Pańskie. Msza św. w dzień, [w:] Mszat z czytaniami. Niedziele..., dz. cyt., s. 296.

107 Por. Modlitwa nad darami. Msze o Najświętszej Maryi Pannie w okresie wielkanocnym, [w:] Mszalik..., dz. cyt., s. 1080. 
swego Ducha" (por. Rz 8, 11). Działanie Trójcy Świętej ad extra, a więc i wobec człowieka jest jedno, angażuje wszystkie osoby Boskie, odpowiednio do trynitarnego porządku. Skoro Duch Święty „mieszka w nas", to prosi w Kościele o powszechne zmartwychwstanie. Już teraz przyczynia się do przyszłego wskrzeszenia umarłych w Chrystusie.

\section{Prośby o następstwa Paruzji}

Nawet adwentowe wołanie: „Przybądź, o Panie i pozostań z nami” wymaga podwójnej interpretacji uwzględniającej przyjście Chrystusa w dniu ostatecznym i Jego przychodzenie w historii. Na takie możliwości wskazuje kontekst. Zwieńczone wezwaniem „Przybądź” prośby o królowanie Chrystusa mogą być spełniane częściowo już teraz, a ostatecznie w Paruzji ${ }^{108}$. Modlitwa mówi też o dniu sądu, co sugeruje znaczenie eschatologiczne. Wielokrotnie w liturgii mamy do czynienia z takimi prośbami o „dobra mesjańskie”, których spełnianie rozpoczyna się już w doczesności, dzięki ofierze paschalnej Chrystusa oraz Jego przychodzeniu w Eucharystii i w całej rzeczywistości eklezjalnej, a które swoją realizację osiągną dzięki Paruzji. Do takich dóbr należy sprawiedliwość.

\section{Prośba o sprawiedliwość}

Sprawiedliwość Boża wiąże się w szczególny sposób z Osobą Ducha Świętego. To On poucza o sprawiedliwości (por. J 16, 8). Sprawiedliwość jest owocem Jego obecności i działania. Wykładnię tego, czym jest Boża sprawiedliwość, znajdujemy w nauczaniu współczesnych papieży ${ }^{109}$. W tym miejscu warto przypomnieć, że nie jest ona dobrem, którego w pełni można by doświadczyć na tej ziemi ${ }^{110}$. Toteż wszelkie prośby o wybawienie od zła, które są ostatecznie wołaniem o sprawiedliwość, należy wiązać z Paruzją ${ }^{111}$.

W 3 niedzielę Adwentu Kościół modli się słowami Psalmu 146(145), które przeplata refren: „Przybądź, o Panie, aby nas wybawić”. O jakie przyjście prosi liturgiczne zgromadzenie wiernych? Na pewno chodzi tu o historyczne przypomnienie oczekiwania sprzed wieków. W tym sensie jest to retrospektywne wołanie o przyjście Odkupiciela, o Boże

108 Por. Prośby II nieszporów 1 niedzieli adwentu, [w:] Liturgia Godzin, t. I..., dz. cyt., s. $142 n$.

109 Por. np. DeV 27.

110 Por. Benedykt XVI, encyklika Spe salvi (dalej: SpS) 43.

111 Por.Refren psalmuresponsoryjnego. 3 niedziela adwentu,[w:]Mszatz czytaniami. Niedziele..., dz. cyt., s. 75 . 
Narodzenie. W tekście psalmu słyszymy jednak wołanie o sprawiedliwość tu i teraz, o pomoc uciśnionym współcześnie, o realizowanie się misterium odkupienia w naszych czasach. Poza tym jest to przecież prośba o Bożą sprawiedliwość, o wybawienie, które pochodzi od Boga, a które ostatecznie i trwale dokona się dzięki Paruzji ${ }^{112}$. Czy mamy więc do czynienia z liturgiczną retrospekcją, czy z wołaniem o pomoc Bożą w naszych czasach, czy wreszcie z prośbą o ostateczną, eschatyczna sprawiedliwość? Która interpretacja znajduje największe uzasadnienie? Wydaje się, że wszystkie trzy są uprawnione. Z podobną sytuacją

Teologia pastoralna spotykamy się w 4 niedzielę Adwentu. Refren: „Przybądź, o Panie, Tyś jest Królem chwały" zostaje zastosowany do Psalmu 24(23), który mówi o nagrodzie zbawionych, o zapłacie od Boga. Już samo to ma wymowę wyraźnie eschatologiczną. W psalmie podsumowanie życia sprawiedliwego wiąże się z tryumfalnym przybyciem Króla chwały, do którego należy cała ziemia ${ }^{113}$. Wyrażenie „cała ziemia” wskazuje, że mamy do czynienia nie tylko z indywidualną nagrodą, ale $\mathrm{z}$ wołaniem o to, by sprawiedliwość przychodzącego Pana zatryumfowała powszechnie.

W powyższych tekstach nie ma wzmianki o Duchu Świętym, ale przecież to On inspiruje tę modlitwę. Na jakiej podstawie można tak powiedzieć? Duch Święty ośmiela Kościół do prośby o zbawienie, ponieważ to sam Bóg pragnie tę sprawiedliwość okazać. Potwierdzenie tej, płynącej z nieba, inspiracji można odczytać w Antyfonie na Komunię 3 niedzieli Adwentu, zachęcającej do odważnego oczekiwania na spełnienie się obietnic Bożych ${ }^{114}$.

Sprawiedliwość oznacza uwolnienie od zła, czyli ostateczną wolność Kościoła. Duch Święty, który poucza o sprawiedliwości, sprawia, że wołanie o nią nie ustaje przez wieki. Ostateczna sprawiedliwość to ta, jaką Ojciec okazuje Synowi ${ }^{115}$. Wzbudzane przez Ducha Świętego błaganie nie ogranicza się więc do rozumianego negatywnie uwolnienia, czy wybawienia. Dzięki Duchowi Świętemu Kościół ma odwagę prosić, by ta trynitarna sprawiedliwość ojcowskiego miłowania bez końca stała się udziałem całego Mistycznego Ciała Chrystusa.

Głos Ducha Świętego przypomina i poucza w modlitwach Kościoła, że przyjście Pana wiąże się z ostateczną sprawiedliwością i uwolnieniem od zła. Sprawiedliwość, jaką Ojciec okazuje Synowi, dopełnia dzieła, które wyprowadza wiernych z lęku, z obawy przed

Por. SpS 43.

Por. Refren psalmu responsoryjnego. 4 niedziela adwentu, tamże, s. 95.

Por. Antyfona na Komunię 2 niedzieli adwentu, [w:] Mszalik..., dz. cyt., s. 57.

Por. DeV 27. 
sądem i pociąga ku świętości trynitarnej ${ }^{116}$. Wiersze przed Ewangelia z końca Adwentu wyrażają pragnienie tej sprawiedliwości. Wypełnia je błaganie o uwolnienie od ciemności, więzienia i śmierci ${ }^{117}$, a więc o doczesne wyzwolenie z grzechów i o przyszłe, radykalne uwolnienie od wszelkiego zła. Wiersze mówią o wybawieniu, które ma się dokonać w wymiarze globalnym, dla „narodów” ${ }^{118}$, tak, jak powszechne jest dzieło zbawienia i jak uniwersalna będzie Paruzja. Podobnie wobec dualizmu znaczeniowego modlitwy o nową ziemię, w której zamieszka sprawiedliwość i pokój ${ }^{119}$, możemy pytać, czy chodzi tu o odnowienie dostępne w doczesności, czy o to ostateczne. Mamy jednak pewność, że sprawiedliwość i pokój to owoce Ducha, o które prosimy wraz z Nim i które On wnosi w ludzką rzeczywistość (por. Ga 5, 22).

\section{Prośba o miłosierny sąd}

W mszalnych aktach pokuty znajduje się prośba o zmiłowanie skierowana do Chrystusa, który przyjdzie nas sądzić ${ }^{120}$. Prośba ta odnosi się do miłosierdzia, które ma być okazane od razu, ale, ponieważ wspomina o przyszłym sądzie, można ją interpretować szerzej: „Zmiłuj się teraz i gdy przyjdziesz”, albo: „Odpuść grzechy teraz, aby nie obciążały nas na sądzie”. W adwentowych modlitwach obok próśb o miłosierdzie w doczesności, spotykamy takie, które wiążą się z Paruzją i w jej kontekście, a raczej w kontekście przyszłego sądu, wołają o litość i zmiłowanie ${ }^{121}$. Adwentowe Przybadź nabiera w nich znaczenia: „Nawiedź nas teraz, w historii, abyśmy byli gotowi na tamto przyjście”.

Prośby o miłosierdzie przy Paruzji wyrażają świadomość, że zasługujemy na karę ${ }^{122}$. Brewiarzowe hymny w skierowanych do Boga Ojca inwokacjach przywołują grozę przyszłego, „straszliwego sądu" ${ }^{123}$. Zwracają się do Chrystusa z prośbą, aby wyrok sądu nie

$116 \quad$ Por. DeV 48.

117 Por. Wiersze przed Ewangelia (4) i (5). 17-24 grudnia, [w:] Mszat z czytaniami..., dz. cyt., s. 1316-1317.

Por. Wiersze przed Ewangelia (3), tamże, s. 1316.

Por. Prośbyjutrzni 3 tygodnia adwentu, [w:] Liturgia Godzin, t. I..., dz. cyt., s. 244.

Por. Akt pokuty, [w:] Mszatz czytaniami..., dz. cyt., s. 615; [w:] Mszat z czytaniami. Niedziele..., dz. cyt., s. 614.

Por. Prośby I nieszporów 2 niedzieli adwentu, [w:] Liturgia Godzin, t. I..., dz. cyt., s. 183; Prośby nieszporów. Piątek 2 tygodnia adwentu, tamże, s. 221.

Por. Hymn Godziny Czytań. Wniebowstapienie, [w:] Liturgia Godzin, t. II..., dz. cyt., s. 714.

Por. Hymn I nieszporów niedzieli 2 tygodnia, [w:] Liturgia Godzin, t. III..., dz. cyt., s. 672 . 
Teologia pastoralna oznaczał potępienia. Słyszymy w nich obawy, podkreślenie „gniewu Odkupiciela", a nie radosny ton oczekiwania na spotkanie z Nim ${ }^{124}$. Piękny hymn Dies irae opowiada w poetycki sposób o dniu gniewu i pomsty, a nie o radości powszechnego zmartwychwstania i spotkania ze Zmartwychwstałym Panem. Nic dziwnego, że znajdujemy w nim prośbę o miłosierdzie i przebaczenie, ale nie o rychłą Paruzję i nadejście dnia sądu ${ }^{125}$. Hymny modlitwy Kościoła posługują się pewną antynomią: pełen gniewu Sędzia jest w nich nazwany Odkupicielem ${ }^{126}$. Groza „straszliwego sądu” Pana Jezusa zostaje zestawiona z Jego przynoszącym radość i wytchnienie ,pokojem wiekuistym” ${ }^{127}$. W tych antynomiach odczytujemy działanie Ducha Świętego, który „przychodzi z pomocą naszej słabości" (por. Rz 8, 26) i poucza o sądzie (por. J 16, 8). Owszem, kara jest należna, ale groza sądu nie musi oznaczać wiecznej przepaści. Duch Święty - osobowa Miłość Trójcy i Sprawca radości - ośmiela Kościół, aby powoływał się na zbawczą ofiarę Chrystusa i oczekiwał chwały.

Ze stwierdzeniem „Ty przyjdziesz jako Sędzia” związane są prośby o wynik sądu ${ }^{128}$, o wybawienie od cierpień i kary ${ }^{129}$. Wspólnota wiernych wielokrotnie kieruje do Chrystusa prośby nie tyle o przyjście, ile o zbawienie przy wskrzeszeniu umarłych ${ }^{130}$, czy o miłosierdzie podczas sądu ${ }^{131}$.

Kościół zanosi błagania, aby Pan Jezus przyszedł i wybawił od śmierci wiecznej, aby ocalił swój Lud ${ }^{132}$. Znów możliwe są dwie interpretacje; ocalenie ludu „na wieki” odnosi się do wieków zmagań, które jeszcze czekają go na ziemi, lub do ocalenia ostatecznego. „Wybawienie od śmierci" ma sens moralny ocalenia od „śmierci grzechu” i eschatologiczny - od śmierci drugiej, wiecznej, czyli od potępienia. Czy nie brzmi w tych prośbach inspirujący głos Ducha Parakleta - Obrońcy?

124 Por. Hymn Godziny Czytań. Sobota 1 tygodnia, tamże, s. 661.

125 Por. Hymny 34 tygodnia zwyklego, [w:] Liturgia Godzin, t. IV..., dz. cyt., s. 461nn.

Por. Hymn Godziny Czytań. Środa 1 tygodnia, [w:] Liturgia Godzin, t. III..., dz. cyt., s. 612.

Por. Hymn I nieszporów niedzieli 2 tygodnia, [w:] Liturgia Godzin, t. IV..., dz. cyt., s. 628.

Por. Hymn Ciebie, Boga wystawiamy, [w:] Liturgia Godzin, t. III..., dz. cyt., s. 537.

Por. Prośby jutrzni 22 grudnia, [w:] Liturgia Godzin, t. I..., dz. cyt., s. 329.

Por. Prośby I nieszporów 25 marca, [w:] Liturgia Godzin, t. II..., dz. cyt., s. 1310.

Por. Litania do Wszystkich Świętych; Hymn II nieszporów. Teksty wspólne o Apostołach w wielkim poście, tamże, s. 1569.

Por. Prośby nieszporów 3 tygodnia adwentu, [w:] Liturgia Godzin, t. I..., dz. cyt., s. 265; Antyfona na wejście. 12 niedziela zwykta, [w:] Mszalik..., dz. cyt., s. 584. 
Dzięki Niemu Kościół nie pragnie uniknąć dnia sądu i odsunąć Chrystusowego przyjścia, ale prosi, by przy Paruzji, w wyniku sądu wejść do chwały ${ }^{133}$.

\section{Prośby o radość życia wiecznego}

Eschatyczna radość życia wiecznego to także skutek Paruzji. Wstępem do niej jest upodobnienie do Chrystusa tak, byśmy mogli mieć udział w życiu Trójcy jako „synowie w Synu”.

Czy zatem wyjątkowa prośba, aby Pan Jezus przemienił umarłych na swoje podobieństwo dotyczy ich zmartwychwstania? ${ }^{134} \mathrm{Czy}$ może chodzi o duchowe podobieństwo i synowskie odniesienie do Teologia Ojca? Mszalne antyfony wskazują już wprost na Paruzję, gdy mówią u upodobnieniu do Chrystusa wtedy, gdy Go ujrzymy ${ }^{135}$. Modlitwa po Komunii dopowiada, że wtedy również będziemy mieć udział w Boskim życiu Ojca ${ }^{136}$. Nasuwa się skojarzenie z trynitarną epifanią nad Jordanem, której treścią było „upodobanie” Ojca względem Syna. Odkrywamy więc także tutaj dyskretną obecność Ducha Świętego, który upodabnia synów ludzkich do Zbawiciela, by jako "synowie w Synu“ byli umiłowani przez Ojca. Te i podobne modlitwy, by Ojciec dał nam uczestniczyć w Bóstwie swojego Syna ${ }^{137}$, wprowadzają w przestrzeń liturgicznego ,już i jeszcze nie”. W ich tle domyślamy się prośby „nie wprost”, aby objawił się Chrystus, dzięki któremu będziemy mieli udział w życiu Boga.

Upodobnienie pozwala uczestniczyć w prawach Syna. Niejednokrotnie prośba o to, co ma nastąpić w wyniku Paruzji dotyczy bogactwa Jego darów ${ }^{138}$. Największym i najważniejszym z tych darów jest „połączenie z Nim w wieczności”"139. udział w Jego chwale, życie w jedności z Nim, w którą wprowadza Duch Święty ${ }^{140}$. Powtarzane

${ }_{133}$ Por. Prośby jutrzni. Środa w oktawie Wielkiejnocy, [w:] Liturgia Godzin, t. II..., dz. cyt., s. 460.

Por. Prośby nieszporów wtorku 4 tygodnia wielkanocnego, [w:] Liturgia Godzin, t. II..., dz. cyt., s. 611.

Por. Antyfona na Komunię. Przemienienie Pańskie, [w:] Mszalik..., dz. cyt., s. 1031; Antyfona na Komunię. 28 niedziela zwykła, tamże, s. 794.

Por. tamże.

Por. Kolekta. Msza św. w dzień. Narodzenie Pańskie, tamże, s. 87; Modlitwa nad darami, tamże, s. 91.

Por. Prośby nieszporów 20 grudnia, [w:] Liturgia Godzin, t. I..., dz. cyt., s. 317.

Por. Prośby nieszporów 21 grudnia, [w:] Liturgia Godzin, t. I..., dz. cyt., s. 325.

Por. Prośby nieszporów. Chrystusa Króla, [w:] Liturgia Godzin, t. IV..., dz. cyt., s. 460 . 
Teologia pastoralna

w liturgii prośby o „wieczne dziedzictwo” dotyczą właśnie udziału w tym, co należy do Syna Bożego, do Jego sposobu bytowania ${ }^{141}$. Ponieważ liturgia mówi, że mamy otrzymać je ,po wyzwoleniu z grzechu i śmierci" ${ }^{142}$, można uznać, że Kościół zwraca się w tych modlitwach z prośbą o nadejście tej rzeczywistości, którą rozpoczyna Paruzja. Modlitwy „na poświęcenie kościoła” wskazują na eklezjalny aspekt tej rzeczywistości, jaką jest przebywanie wraz z Chrystusem w domu Ojca; rzeczywistości przedstawionej we wspólnotowym obrazie Miasta - Nowego Jeruzalem ${ }^{143}$.

Dzięki upodobnieniu do Syna Bożego zbawiony dostępuje udziału w Jego radości. Razem z Nim ogląda Ojca. Gdy Kościół modli się, byśmy stali się ,wieczystym darem” dla Ojca przez Syna, obejmuje błaganiem rzeczywistość, która rozpoczyna się już teraz, przed Paruzją ${ }^{144}$. Niekiedy jednak słowa liturgii nie pozostawiają wątpliwości, że chodzi o uczestniczenie w „radości Syna w niebie” ${ }^{145}$, w wiecznej chwale ${ }^{146}$. Prośba o oglądanie Boga podkreśla indywidualny aspekt zbawienia ${ }^{147}$. Godne zauważenia jest to, że liturgia uwzględnia trynitarny charakter visio beatifica i włącza tę prośbę w treść Błogosławieństwa o Duchu Świętym, widząc w Nim Tego, który prowadzi od wzbudzenia nadziei aż do jej spełnienia ${ }^{148}$. Należy w tym miejscu zwrócić uwagę na coś jeszcze: papież Benedykt XII w konstytucji Benedictus Deus pisze, że zbawieni jeszcze przed Sądem Ostatecznym radują się oglądaniem Boga ${ }^{149}$. Nie przeczy to oczywiście temu, że powszechne zmartwychwstanie ma istotne znaczenie w dopełnieniu się zbawczego planu Stwórcy. Natomiast wszelkie prośby o włączenie w widzenie uszczęśliwiające mogą dotyczyć radości świętych jeszcze przed Paruzją.

Szczególne miejsce, jeśli chodzi o przejawy działania Ducha Świętego, zajmują prośby o radość, bo przecież to On jest osobową Radością Trójcy i Sprawcą wiecznej radości.

141 Por. Kolekta. 20 niedziela zwykta, [w:] Mszat z czytaniami. Niedziele..., dz. cyt., s. 1250; Kolekta. 21 niedziela zwykta, tamże, s. 1279.

4 Modlitwa eucharystyczna, [w:] Mszalik..., dz. cyt., s. 484.

Por. Prośbyjutrzni na poświęcenie kościoła, [w:] Liturgia Godzin, t. II..., dz. cyt., s. 1522.

Por. Modlitwa nad darami, 18 niedziela zwykta, [w:] Mszalik..., dz. cyt., s. 904.

Por. Kolekta. Boże Narodzenie. Msza Święta w nocy, tamże, s. 80; Kolekta. 2 niedziela Bożego Narodzenia, [w:] Mszat z czytaniami. Niedziele..., dz. cyt., s. 155.

Por. Modlitwa po Komunii. 28 niedziela zwykła, tamże, s. 1472.

Por. Kolekta. 2 niedziela Bożego Narodzenia, tamże, s. 155.

Por. 9 Btogostawieństwo o Duchu Świętym, tamże, s. 719.

Por. Konstytucja Benedictus Deus, BF..., dz. cyt., s. 108. 
Liturgia nie zapomina o aspekcie moralnym i indywidualnym: na radość wieczną trzeba zasłużyć, ale, aby stać się jej godnym, niezbędna jest pomoc Boża ${ }^{150}$. Radość wieczna może być już teraz antycypowana. Doświadczenie to nie jest jedynie skutkiem ludzkich wysiłków, ale darem. Dlatego Kościół nie zapomina o prośbie, abyśmy dążąc ku wieczności, już teraz mogli doświadczyć obiecanego szczęścia ${ }^{151}$. Dokąd trwa ten świat, antycypowaną radość nieba można przeżywać jedynie wśród trosk i cierpień. Dlatego modlitwa o uwolnienie od doczesnych utrapień, nawet jeśli obejmuje ich przejściowe zniwelowanie, docelowo dotyczy radykalnego od nich uwolnienia, które dokona się „przez Chrystusa”, przy Jego przyjściui ${ }^{152}$. Jest to więc modlitwa nie wprost o Paruzję.

Wśród próśb o właściwe przygotowanie do życia wiecznego, o udział w nim uczestników liturgii, nierzadko znajduje się motyw „dojścia” do wieczności, czy doprowadzenia do niej Kościoła przez Eucharystię ${ }^{153}$. Również w Modlitwie św. Tomasza brzmi ta sama myśl; „abyś mnie grzesznika doprowadził do niebieskiej uczty" ${ }^{154}$. W porównaniu z $D i$ dache mamy tu do czynienia z odwróceniem kierunku: od „przyjdź” do „przyprowadź mnie do siebie”. Indywidualne przyjście do Chrystusa akcentuje już nie Paruzję, ale doświadczenie szczęścia po śmierci, jeszcze przed powszechnym zmartwychwstaniem.

Przyjściu Chrystusa towarzyszy radość. O tę radość modli się Kościół ${ }^{155}$. To samo pragnienie radości, ale wiecznej, po Paruzji, wyraża przez metaforę uczty, gdy Chrystus zgromadzi „wszystkich“, a więc „po wszystkim” ${ }^{156}$. Modlitwy o „szczęśliwą wieczność” również należą do zakresu eschatologicznego ,już i jeszcze nie”. Można przyjąć, że chodzi w nich o „otarcie łez”, czyli o pocieszenie, o przebywanie w obliczu wiecznego Boga po śmierci, ale jeszcze przed powszechnym

150 Por. Modlitwa Wigilii Paschalnej, [w:] Mszalik..., dz. cyt., s. 280.

Por. Kolekta. 26 niedziela zwykła, tamże,s. 782.

Por. Kolekta. Msza ogólna o Najświętszej Maryi Pannie, [w:] Mszat z czytaniami. Niedziele..., dz. cyt., s. 1435.

Por. Kolekta. Uroczystość Świętej Rodziny, [w:] Mszalik..., dz. cyt., s. 92; Modlitwa nad darami. 17. niedziela zwykła, tamże,s. 900; Prośby jutrzni. Wielki Poniedziatek, [w:] Liturgia Godzin, t. II..., dz. cyt., s. 335.

Liturgia Godzin, t. I..., dz. cyt., s. 1366.

Por. Błogostawieństwo wadwencie, [w:] Mszat z czytaniami. Niedziele..., dz. cyt., s. 703, 716; Kolekta. Piątek 6 tygodnia wielkanocnego, tamże, s. 573.

Por. Kolekta. 4 niedzieli wielkanocnej, [w:] Mszalik..., dz. cyt., s. 341; Modlitwa po Komunii, tamże, s. 344; 2 Modlitwa eucharystyczna o tajemnicy pojednania, [w:] Mszat z czytaniami. Niedziele..., dz. cyt., s. 699. 
Teologia pastoralna zmartwychwstaniem ${ }^{157}$. Niemniej jednak zastosowanie cytatu z Apokalipsy: „gdy otrzesz z naszych oczu wszelką łzę” (por. Ap 21, 4) sugeruje, że teksty te dotyczą ostatecznej nagrody w wiecznym Jeruzalem ${ }^{158}$. Podobnie, słowa o „radości przywróconej światu” każą myśleć o nadziei zbawienia, ale i o ostatecznej przemianie wszechrzeczy, o trwałej radości nowego stworzenia ${ }^{159}$, tym bardziej, że modlitwa kierowana jest za pośrednictwem Matki Najświętszej, która już uczestniczy w chwale nowego stworzenia. Słowa mówiące o „szczęściu bez końca”"160 oraz o radości po pokonaniu śmierci i oddaniu nas Ojcu ${ }^{161}$ wskazują już bardziej jednoznacznie na to, co nastąpi w wyniku Paruzji: na udział w zwycięstwie Chrystusa, gdy wszystko będzie $\mathrm{Mu}$ poddane, a On Ojcu (por. 1 Kor 15, 28).

Charakterystyczne, że modlitwy o radość wieczną są kierowane do Chrystusa. W historii Chrystus daje radość, pociesza Kościół posyłając Ducha Parakleta. Podobnego porządku ostatecznego pocieszenia oczekujemy przy Paruzji. Nic więc dziwnego, że wspólnota wiernych zwraca się do Chrystusa o dar Ducha Świętego, aby dobrze przygotować się na powrót Zbawiciela ${ }^{162}$. Można powiedzieć, że zanim odważymy się, jako przygotowani, prosić wraz z Duchem Świętym o Paruzję, zanosimy prośbę o dar Tego, który może nas przygotować.

W prośbach związanych z tym, co niesie Paruzja i przyszłe wskrzeszenie umarłych, przeważa raczej cierpliwość niż tęsknota, raczej troska o wynik sądu dla tych, których dotyczy dana modlitwa (są to: zmarli, „my” - modlący się, odkupieni). Więcej w nich świadomości ludzkich braków niż pragnienia pełni - pełni Chrystusowego panowania i dokonania się planu Boga.

Co liturgiczne modlitwy, związane z następstwami Paruzji, mówią o Duchu Świętym? Do jakiej modlitwy Duch Święty inspiruje Kościół? Na pewno okazuje się tu Tym, który czuwa nad nadzieją Ludu Bożego i strzeże go przed złem i grzechem. Duch Paraklet daje się tu poznać jako Stróż i Inspirator nadziei Kościoła. Poucza o grzechu niewiary,

157 Por. Modlitwa nad darami. 33 niedziela zwykta, [w:] Mszalik..., dz. cyt., s. 965.

Por. 3 Modlitwa eucharystyczna, tamże, s. 478n.

Por. Kolekta. Msza o Najświętszej Maryi Pannie w okresie wielkanocnym, [w:] Mszat z czytaniami. Niedziele..., dz. cyt., s. 1441.

Por. Modlitwa nad darami. Poniedziałek w Oktawie Wielkanocy, [w:] Mszalik..., dz. cyt., s. 312 .

161 Por. Hymn Godziny czytań. Niedziela I tygodnia, [w:] Liturgia Godzin, t. III..., dz. cyt., s. 564 .

162 Por.Prośbyjutrzni.Środa 3 tygodnia wielkiego postu, [w:]Liturgia Godzin, t. II..., dz. cyt., s. 194. 
o sprawiedliwości i o sądzie. Zachęca, by pragnąć sprawiedliwości, jaką niesie zwycięstwo Chrystusa i pokornie prosić o miłosierny wynik sądu $^{163}$. W modlitwie dotyczącej następstw Paruzji Duch Święty nie tylko poucza, czy przekonuje. Przejmuje inicjatywę. Jest Inicjatorem tego, na co ludzie nie poważyliby się bez Niego. Pobudza do wyznania wiary, a odrzucenia niewiary, aby świat doznał tej ostatecznej sprawiedliwości, jaką Ojciec okazał Synowi. Prowadzi ku dopełnieniu się dzieła zbawienia.

\section{Modlitwa wprost o Paruzję}

Teologia pastoralna

W modlitwach związanych z Paruzją zwraca uwagę to, że w znacznej mierze odnoszą się do darów, których oczekujemy od Chrystusa przy Jego przyjściu, a nie do samego spotkania z Nim ${ }^{164}$. Gdzie jest tęsknota Oblubienicy - Kościoła, który pomimo obaw związanych z sądem i poczuciem ludzkiej niegodności, pragnie oglądać swego Zbawiciela, cieszyć się Jego pełną obecnością, Jego panowaniem i Zmartwychwstaniem całej wspólnoty świętych? Święty Jan Paweł II jako jeden z owoców Wniebowstąpienia wymienia modlitwę Kościoła zrodzoną z tęsknoty za powrotem Chrystusa: „Przyjdź, Panie Jezu” $(\text { Ap } 22,20)^{165}$. Jaką treść wyraża, bądź ma wyrazić modlitwa odpowiadająca apokaliptycznemu Maranatha? Oczywiście nie powinno w niej brzmieć znudzenie tym światem, czy brak wytrwałości wobec udręk. Spodziewamy się usłyszeć w niej tęsknotę za Panem, za ostatecznym spełnieniem się planu Boga i wołanie o Jego sprawiedliwość.

\section{Ojcze nasz}

Narzucająca się odpowiedź na pytanie: „Czy Kościół modli się o Paruzję?”, brzmi: „Tak, przecież w modlitwie Ojcze nasz prosimy o przyjście Królestwa Bożego, o to, by Bóg był wszystkim we wszystkich”. Taką wykładnię znajdujemy w Katechizmie Kościoła Katolickiego ${ }^{166}$. Zawarte w niej prośby o nadejście Królestwa Bożego i o to, by wola Boża była realizowana na ziemi w sposób doskonały, jak w niebie, można rozumieć jako wołanie o podporządkowanie doczesności prawu Bożemu, lub o nadejście Jego ostatecznego panowania. Również

$\overline{163}$ Por. DeV 27.

Por. 1 Prefacja adwentowa, [w:] Mszalik..., dz. cyt., s. 427.

Por. Jan Paweł II, Wierze w Jezusa Chrystusa Odkupiciela, S. Dziwisz, J. Kowalczyk, T. Rakoczy (red.), Città del Vaticano 1989, s. 622.

Por. KKK 2772; 2804; 2816; 2817; 2118. 
Teologia pastoralna

prośba o wybawienie od „wszelkiego zła” może dotyczyć tego, byśmy podczas ziemskiej pielgrzymki szli wolni od grzechu i zagrożeń zewnętrznych, albo tego, aby ostatecznie, dzięki Paruzji, zło w ogóle zniknęło z naszej perspektywy.

Różne dopowiedzenia towarzyszące modlitwie Ojcze nasz rzutują na rozumienie wypowiadanych słów. I tak np. następująca po niej prośba o obdarzenie „naszych czasów” pokojem, po wybawieniu nas od zła, sugeruje interpretację doczesną ${ }^{167}$. Także brewiarzowe rozwinięcie $O j$ cze nasz wymienia cechy panowania Bożego rozpoczynającego się już na ziemi, w sercach ludzkich - usunięcie z nich nienawiści, pychy, pogardy, a napełnienie ich „owocami Ducha” - łagodnością i pokojem ${ }^{168}$. W innym miejscu skierowane do Boga Ojca wołanie o przyjście Jego Królestwa obejmuje upragnione w doczesności, ale przecież aktualne wiecznie dobra duchowe, takie, jak jedność i uwielbienie Boga ${ }^{169}$. Nie można więc jednoznacznie powiedzieć, że Kościół prosi w Ojcze nasz wyłącznie o radykalną przemianę, o eschatyczne poddanie wszystkiego Bogu, a nie np. o panowanie ładu Bożego na ziemi.

\section{Przyjście ostateczne czy przychodzenie w historii?}

Trudno jest znaleźć takie miejsce w liturgii, które można by zakwalifikować jako wołanie wyłącznie o Paruzję. Dlaczego? W pierwszej chwili narzuca się odpowiedź, że wystarczy starać się o gotowość moralną, a ponieważ Pan Bóg sam decyduje o Paruzji i zakończeniu dziejów, prośba taka byłaby czymś niestosownym. Takie wyjaśnienie jest jednak mylące. Podobne zastrzeżenia wysuwają protestanci odnośnie np. modlitwy za zmarłych, na zasadzie, że Boża decyzja jest suwerenna i nie potrzebuje żadnych zabiegów ze strony człowieka, można by zresztą podważyć zasadność każdej modlitwy. A jednak Pan Bóg zachęca swój Kościół do współdziałania. Czyni to słowami Pisma Świętego. Kościół zaproszony do wnętrza trynitarnej wymiany ma prawo, wraz z Duchem Świętym, przy Jego pomocy wyrażać swoją tęsknotę za Zbawicielem i nie tylko biernie oczekiwać Jego przyjścia. Trudność w wyróżnieniu modlitwy ukierunkowanej wyłącznie na Paruzję wynika z czego innego: Chrystus nie tylko przyjdzie na końcu czasów, ale raz już przyszedł w historii i stale przychodzi w misterium Kościoła. Liturgia uobecnia retrospektywnie Jego pierwsze przyjście, stanowi

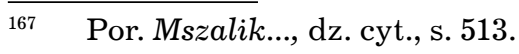

168 Por. Prośby z wtorku 1 tygodnia adwentu, [w:] Liturgia Godzin, t. I..., dz. cyt., S. 154.

169 Por. Prośby nieszporów. Środa 1 tygodnia adwentu, tamże, s. 162. 
szczególną przestrzeń wciąż aktualizującego się sakramentalnego, a zwłaszcza eucharystycznego przychodzenia i wreszcie wychodzi ku temu ostatecznemu. Zatem te trzy interpretacje, zwłaszcza w odniesieniu do adwentowego: „Przyjdź, Panie Jezu”, są jednakowo prawdziwe $\mathrm{i}$ trudne do rozdzielenia. Błaganie zanoszone z radością odzwierciedla działanie Ducha Świętego. Łączy uobecnianie przeszłości, teraźniejsze przygotowanie do Świąt Bożego Narodzenia oraz ostateczne przyjście, i w doczesnym interludium prosi: „Przyjdź, pomóż nam przygotować się na sąd" 170 .

Tę samą potrójną interpretację można zastosować do wołania o zbawienie, odpuszczenie win, czy nawiedzenie w pokoju, o których mówią adwentowe Wiersze przed Ewangelia, dodając do nich inwokację: „Przyjdź, Panie”171. Znajdująca się wśród nich prośba o radość oglądania Boga czystym sercem w szczególny sposób wskazuje na działanie Ducha Świętego. To właśnie poddanie się Jego prowadzeniu umożliwia oglądanie Boga w Prawdzie (por. Mt 5, 3nn) i jest przyczyną radości wiecznej (por. J 16, 22). W Kolekcie 2 niedzieli po Bożym Narodzeniu Kościół wyraża pragnienie, aby cały świat napełniła chwała Boga, a blask Jego prawdy ukazał się narodom ${ }^{172}$. Czy można to uznać za modlitwę o Paruzję, czy raczej o to, by Ewangelia była znana na całym świecie? Podobnie wołanie: „Przyjdź nas uwolnić, racz dłużej nie zwlekać" ${ }^{173}$ może dotyczyć uwolnienia w toku dziejów, jak i ostatecznie. Nieco bardziej eschatologiczne zabarwienie noszą słowa o radości z przyjścia Pana i podniesieniu na duchu oczekujących Go, ponieważ przypominają Jego własną zapowiedź Paruzji (por. Łk 21, 28) ${ }^{174}$.

Chociaż adwentowe „Przybądź” odnosi się często wprost do rzeczywistości związanej z Paruzją - do sądu, do wybawienia od zła i śmierci - nie można jednoznacznie utożsamiać go z wołaniem z Didache: „Niech przeminie ten świat”. Raczej wybrzmiewa w nim prośba o to, by Chrystus był obecny teraz, w doczesności i przychodząc wśród ziemskiego czasu pomógł swojemu ludowi przygotować się na dzień sądu. Teksty te mają potrójne znaczenie: liturgicznego uobecnienia przeszłości i przeżywania tajemnicy Wcielenia i Bożego Narodzenia,

170 Por. Prośby nieszporów wtorku 2 tygodnia adwentu, [w:] Liturgia Godzin, t. I..., dz. cyt., s. 203.

171 Por. Wiersze przed Ewangelia wokresie adwentu, [w:] Mszat z czytaniami. Niedziele..., dz. cyt., s. 1314n.

Por. Kolekta. 2 niedziela po Narodzeniu Pańskim, [w:] Mszalik..., dz. cyt., s. 101.

Por. Śpiew przed Ewangelia. 19 grudnia, [w:] Mszat z czytaniami. Niedziele..., dz. cyt., s. 109.

Por. Kolekta. 24 grudnia Msza poranna, tamże, s. 121. 
eucharystycznego tu i teraz, a także ukierunkowanej eschatycznie prośby ${ }^{175}$. Ze względu na ten potrójny charakter tekstów liturgicznych trudno wyróżnić w nich modlitwę dotyczącą wyłącznie powtórnego przyjścia Pana. Nie można jednak powiedzieć, że nie ma sformułowań, które wyrażałyby tęsknotę za dopełnieniem dziejów, za ostatecznym wybawieniem ,ludu” i za samym Zbawicielem.

\section{Eucharystyczne przychodzenie i wołanie o przyjście}

Teologia pastoralna
Szczególnie istotnym sposobem przychodzenia Chrystusa w historii jest Jego eucharystyczna i sakramentalna obecność. Częstokroć powtarzana prośba o to, by Odkupiciel nawiedził nas w pokoju ${ }^{176}$, by zasiadł z nami do stołu ${ }^{177}$, dotyczą jednocześnie uczty eucharystycznej i ostatecznej. Konstytucja Sacrosanctum Concilium podkreśla, że Kościół wzywa Chrystusa, aby był obecny tu i teraz, w czynnościach liturgicznych ${ }^{178}$. Także do tego eucharystycznego przyjścia można więc odnieść wołanie, aby „nie zwlekał” ${ }^{179}$. Aklamacja „Hosanna” to okrzyk powitania przybywającego Zbawcy - przybywającego w historii do Jerozolimy i w liturgii ${ }^{180}$. To afirmacja Jego powrotu.

Może czymś niestosownym byłaby prośba o przyjście Chrystusa wypowiedziana właśnie wtedy, gdy On rzeczywiście jest obecny, kiedy powraca w „eucharystycznej Paruzji”? Tymczasem, cokolwiek by o tej sakramentalnej Paruzji zostało powiedziane, nie zastępuje ona, ani nie wyczerpuje tego przyjścia, które jeszcze nastąpi ${ }^{181}$. Można też na to spojrzeć inaczej: Modlitwa eucharystyczna jest radosną proklamacją obecności Chrystusa i jednocześnie wołaniem do Niego, aby przyszedł182. Za każdym razem, gdy Kościół celebruje Eucharystię, woła o przyjście Pana - zapewnia Katechizm ${ }^{183}$. Skoro cała Msza św. jest modlitwą o Paruzję, to może nie wymaga detalicznych próśb? Zawsze jednak poszukujemy słów, które to wyrażą.

175 Por. np. Refren psalmu responsoryjnego 4 niedzieli adwentu, tamże, s. 53.

Por. Antyfona na Komunię. Poniedziatek 2 tygodnia adwentu, tamże, s. 63.

Por. Prośby jutrzni. Boże Ciało, [w:] Liturgia Godzin, t. III..., dz. cyt., s. 505.

Por. KL 7.

Por. Śpiew przed Ewangelia. Wtorek 3 tygodnia adwentu, [w:] Mszatz czytaniami. Niedziele..., dz. cyt., s. 86.

Por. Aklamacja zgromadzenia, [w:] Mszalik..., dz. cyt., s. 458.

Por. K. Porosło, „Już’... dz. cyt., s. 188n.

Por. J. Ratzinger, Śmierć i życie wieczne, przeł. M. Węcławski, Warszawa 1986, s. 21.

Por. KKK 1403. 


\section{Wołanie o Paruzję i deklaracja oczekiwania}

\section{Afirmacja powtórnego przyjścia Chrystusa}

Już samo wyznanie gotowości i oczekiwanie życia w komunii z Trójcą Świętą stanowi pośrednio wołanie o Paruzję ${ }^{184}$. Deklarację tę słyszymy w mszalnej aklamacji, wprawdzie w formie stwierdzenia, nie imperatywu, ale odczytujemy w niej radosną gotowość na przyjście Pana, a więc i pragnienie tego wydarzenia ${ }^{185}$. Oczekiwanie, które wyraża wielkosobotni Exultet to oczywiście przywołanie mocy zmartwychwstania $^{186}$. Zdecydowanie eschatologiczna symbolika „dnia”, „słońca nieznającego zachodu" każe myśleć o przyszłym świecie, w którym „nie będzie już nocy” (Ap 21, 25). Natomiast „zapalona świeca” mówi o gotowości moralnej, która wypełnia oczekiwanie.

Również adwentowe oczekiwanie odbywa się w radosnym napięciu. Mówiące o tym refreny i antyfony ${ }^{187}$ to nie tylko suche stwierdzenia. To wyraz niecierpliwości zabarwionej tęsknotą za Chrystusem - uczuć, które należy przypisać działaniu Ducha Świętego w Kościele.

\section{Wołanie o Paruzję}

Niewątpliwie jednoznacznie odnoszą się do Paruzji te teksty liturgiczne, które przywołują nowotestamentalne obrazy i sformułowania, np. te mówiące o przyjściu Chrystusa wraz ze świętymi ${ }^{188}$, czy o „dniu ostatecznym"189. Kościół woła o Paruzję dość wyraźnie, gdy prosi, aby ludzie ujrzeli chwałę Chrystusa, aby oglądali Jego oblicze ${ }^{190}$. Nie jest

184 Por. Prière du Pape Benô̂t XVI. Basilique vaticane. Samedi 27 novembre 2010, http://www.vatican.va/holy_father/benedict_xvi/prayers/documents/ hf_ben-xvi_20101127_vita-nascente_fr.html.

Por. Aklamacja po Przeistoczeniu, [w:] Mszalik..., dz. cyt., s. 464; Śpiew przed Ewangelia. Piatek 1 tygodnia adwentu, [w:] Mszat z czytaniami. Niedziele..., dz. cyt., s. 48; Śpiew przed Ewangeliq. Jezusa Chrystusa Króla Wszechświata, tamże, s. 1673.

Por. Exultet, [w:] Mszalik..., dz. cyt., s. 273.

Refren psalmu responsoryjnego 1 niedziela adwentu, [w:] Mszat z czytaniami. Niedziele..., dz. cyt., s. 53; Antyfona na Komunię. Antyfona na wejście. 1 tydzień adwentu, tamże, s. 42-46.

Por. Antyfona na wejście. Wtorek 2 tygodnia adwentu, tamże, s. 63; Prefacja o Jezusie Chrystusie Królu Wszechświata, [w:] Mszalik..., dz. cyt., s. 446.

Por. Modlitwa wiernych. Uroczystość Chrystusa Króla Wszechświata, [w:] Mszat z czytaniami..., dz. cyt., s. 635.

Por. Antyfona na wejście. Sobota. 1 tydzień adwentu, [w:] Mszat z czytaniami. Niedziele..., dz. cyt., s. 49; Prośby nieszporów. Piątek. 2 tydzień adwentu, [w:] Liturgia Godzin, t. I..., dz. cyt., s. 224. 
to już tylko prośba o eucharystyczne przychodzenie. „Oglądanie” Chrystusa rozumiane w świetle Pawłowej antynomii „słyszenie” teraz - „widzenie” w wieczności (por. 2 Kor 5, 7) oznacza pełne poznanie Zbawiciela na końcu czasów. Jeszcze intensywniej brzmią słowa z brewiarzowego hymnu, w którym po przywołaniu obrazów Chrystusa - Króla i Sędziego oddzielającego dobro od zła (por. Ap 1, 16) i Miasta - Nowego Jeruzalem, następują wezwania odnoszące się bezpośrednio do eschatycznego powrotu Zbawiciela ${ }^{191}$.

Należy podkreślić trynitarne ujęcie próśb o Paruzję. Hymn, który

Teologia pastoralna zwraca się do Chrystusa, mówi o „domu Ojca” i pojednaniu wszystkich $^{192}$. W podtekście odnajdujemy Osobę Ducha Świętego, który jedna ludzkość z Bogiem, bo sam jest osobową Jednością Trójcy. Przebywanie w „domu Ojca” to przecież nic innego jak uczestniczenie w trynitarnej komunii.

Liturgia Kościoła mówi wreszcie nie tylko o Paruzji, ale o tym, że to Duch Święty przyzywa Zbawiciela. Odwołuje się przy tym do słów Apokalipsy (por. 22, 17) ${ }^{193}$. Chrystus jest radością dla oczekujących Go ${ }^{194}$. To Duch - Sprawca radości pozwala ją odkryć i w jej atmosferze kierować prośby o pokonanie śmierci przy przyjściu Pana ${ }^{195}$. W tchnieniu tej eschatycznej radości, której przyczyną jest oczekiwana obecność Chrystusa, odkrywamy nie tylko inspirację Ducha Świętego, ale Jego samego. Duch i Oblubienica proszą wspólnie modlitwą, która napełnia stworzenie radością przyszłego spełnienia.

\section{Dyskusja}

Czy współczesny Kościół modli się o Paruzję? Trudno znaleźć w tekstach liturgicznych takie sformułowanie, które wprost i jednoznacznie można by uznać za odpowiednik starożytnego: „Niech przeminie ten świat...". Tym niemniej adwentowe modlitwy, nawet przy uwzględnieniu różnorodnej interpretacji, wskazują na to, że choćby w sposób nieśmiały, ale również współczesny Kościół prosi o powtórne przyjście Chrystusa. Nie jest to jednak oczywiste. Autorytet Josepha Ratzingera

191 Por. Hymn Godziny Czytań. Niedziela 4 tygodnia, [w:] Liturgia Godzin, t. IV..., dz. cyt., s. 863.

Por. Hymn jutrzni. Adwent, [w:] Liturgia Godzin, t. I..., dz. cyt., s. 129.

Por. Hymn Godziny Czytań. 27 grudnia, tamże, s. 1006.

Por. Prośby I nieszporów 3 niedzieli adwentu, [w:] Liturgia Godzin, t. I..., dz. cyt., s. 231.

Por. Prośby I nieszporów 1 niedzieli adwentu, [w:] Liturgia Godzin, t. I..., dz. cyt., s. 133. 
mówi, że w adwentowym „Przybądź” nie prosimy po prostu o Paruzję. Byłaby to prośba zbyt wielka dla nas wszystkich, prośba, której nie śmielibyśmy z całą powagą wyrazić ${ }^{196}$. Zdaniem przyszłego Papieża bo słowa te padły w 2003 roku - Kościół prosi o przychodzenie Boga w historii ${ }^{197}$. Według takiej interpretacji, w naszej epoce eklezjalna świadomość eschatycznego ,już i jeszcze nie” wyraża się w imperatywie: „Przyjdź, nie zwlekaj, ale... skoro nie przychodzisz, pomóż nam dobrze spożytkować czas, bądź obecny w naszej historii”.

Powstaje pytanie, co zrobić z natchnionym tekstem, który przekonuje, że „Duch i Oblubienica mówią: «Przyjdź»"? Odłożyć na bok, dla innej epoki i nie podejmować wcale? Jeżeli miałoby się to dziać z nieśmiałości, to przecież właśnie Duch Święty przyczynia się za nami wtedy, gdy nie umiemy się modlić (por. Rz 8,26). Jego udział w tej modlitwie upoważnia do jej podejmowania. Wobec tego pojawia się kolejna kwestia, dlaczego „Duch i Oblubienica” mają wołać o Paruzję? Dlaczego Kościół nie ma jedynie oczekiwać powrotu Pana, koncentrując się na moralnej gotowości?

W innym miejscu Joseph Ratzinger mówi: „Kościół jest procesem włączania ludzkości w sposób życia trynitarnego Boga"198. Dlatego Duch Święty włącza mistyczną wspólnotę Kościoła w trynitarną akcję przychodzenia Pana. Chrystusowa Paruzja nie jest czymś zewnętrznym wobec życia Kościoła - nie przerwie go przecież, ale dopełni. Nie jest też, tym bardziej czymś zewnętrznym wobec miłości, jaką Bóg w Trójcy Jedyny obejmuje już nie tylko osoby, ale całe stworzenie. Kościół w doczesności przyczynia się do przemiany stworzenia, do tej przemiany, której ostatecznie dokonać może tylko Chrystus, tylko Jego przyjście, czyli pełnia obecności.

Joseph Ratzinger mówi, że dzisiejsze czasy nie podejmują śmiałego wołania z Apokalipsy. Jeżeli nie zyskuje ono dzisiaj wprost swojej ekspresji, to może kryje się w prośbach do końca niewypowiedzianych? Może takie znaczenie ma właśnie modlitwa o to, o co „nie ośmielamy się prosić"? ${ }^{199}$ Domyślamy się, że pod tym sformułowaniem kryje się cały zestaw próśb, których wierni nie mają odwagi wygłosić w swojej pokorze i poczuciu niegodności. Czy prośba o Paruzję należy do tego

196 Por. J. Ratzinger, „Wzbudź Twa potęgę i przyjdż”. Kazanie adwentowe wygtoszone w katedrze trewirskiej 4. XII. 2003 na temat następujacych tekstów Pisma Świętego: Iz 26, 1-6, Ps 118, Mt 7, 11-27, [w:] Teologia liturgii...dz. cyt., s. 657.

197 Por. tamże.

198 Tenże, Kościót - znak..., dz. cyt., s. 469.

199 Por. Kolekta. 27 niedziela zwykta, [w:] Mszalik..., dz. cyt., s. 639, 939; Modlitwa na 27 tydzień zwykty, [w:] Liturgia Godzin, t. IV..., dz. cyt., s. 39. 
rodzaju niewypowiedzianych błagań? Nie ośmielamy się o nią prosić, bo człowiek nie wymyśliłby i nie mógłby sam z siebie zapragnąc tego, aby Bóg dał mu miejsce „w swoim domu”, aby zechciał być „Bogiem z nami”. Dowodzi tego pogańskie wyobrażenie wieczności, które zrodziło co najwyżej „pola elizejskie”, ale nie myśl o powszechnym powołaniu do świętości, czyli o uczestnictwie w życiu samego Boga.

Czy jednak to, o co „nie ośmielamy się prosić” to nie za mało, jak na zapowiedziane w natchnionym tekście, śmiałe przecież wołanie Ducha i Oblubienicy? Czy świadczy o dostatecznym „dopuszczeniu

Teologia pastoralna do głosu" Ducha Parakleta? Gdy św. Paweł mówi, że Duch Święty porusza Kościół błaganiem, którego nie jesteśmy w stanie wyrazić słowami, przypomina, że właśnie tej ożywiającej obecności Ducha Prawdy wspólnota wiernych zawdzięcza modlitwy o to, co nie poznane jeszcze, ale obiecane i pewne. Słowa Apokalipsy o Duchu Świętym i Oblubienicy świadczą, że Chrystus, który miłuje Kościół, oczekuje takiego wołania.

\section{Zakończenie}

We współczesnych tekstach liturgicznych spotykamy wiele sformułowań dotyczących przygotowania się wspólnoty wiernych na przyjście Pana. Znajdują się wśród nich prośby o właściwą dyspozycję i „pragnienie nieba" ${ }^{200}$. Dość liczne są też modlitwy związane z tym, co nastąpi, gdy Chrystus powróci: o zmartwychwstanie, o zmartwychwstanie w chwale, o zmiłowanie, o miłosierny wynik sądu, o nagrodę wieczną, o radość życia wiecznego, o szczęście bez końca, czyli o dary, których oczekujemy od Pana, uwarunkowane oczywiście spotkaniem z Nim samym.

Trudno „wyizolować” modlitwę o Paruzję, ponieważ, zwłaszcza w odniesieniu do Mszy św., możliwy jest potrójny ciąg interpretacyjny. Nawet bezpośrednie: Przyjdź, Panie Jezu! Może dotyczyć zarówno uobecniania wydarzeń zbawczych z przeszłości, eucharystycznego przychodzenia Chrystusa do zgromadzonej przy ołtarzu wspólnoty, czy - szerzej - Jego obecności w historii, czy wreszcie eschatycznej przyszłości. Nie ma jednobrzmiącego: „Przyjdź, Panie Jezu, tu na ołtarzu i przyjdź tak, jak obiecałeś, do całego świata, aby Twoje przyjście stało się widoczne i oczywiste, jak błyskawica od jednego krańca widnokręgu aż do drugiego" (por. Łk 17, 24). Jeżeli przebija się taka myśl, to w sposób nieśmiały i nie bezpośrednio. Zdecydowanie przeważają

200 Por. Modlitwa po Komunii. Czwartek 6 tygodnia wielkanocnego, [w:] Mszat z czytaniami. Niedziele..., dz. cyt., s. 573. 
modlitwy o dyspozycję i o dobra wieczne związane z Paruzją. Być może przyjście Chrystusa na końcu czasu - choć tak bogate w treść i decydujące - zajmuje mniej miejsca w liturgii ze względu na swoją „jednorazowość"?

Czy można na tej podstawie cokolwiek powiedzieć o Duchu Świętym, skoro to On modli się wraz z Kościołem o przyjście Zbawiciela? Duch Święty - Sprawca radości i wdzięczności (por. Ga 5, 22) daje o sobie znać w eucharystycznym dziękczynieniu, jakim jest np. Didache. Dlatego w prośbie o Paruzję, gdziekolwiek jest zanoszona brzmi tęsknota i wdzięczność, a towarzyszy radość.

Słowa kluczowe: Duch Święty, Paruzja, Kościół, liturgia, pokój, radość. 